\title{
New Soluble-Polymer Bound Ruthenium Carbene Catalysts: Synthesis, Characterization, and Application to Ring-Closing Metathesis
}

\author{
Stéphane Varray, René Lazaro, J ean Martinez, and Frédéric Lamaty* \\ Laboratoire des Aminoacides, Peptides et Protéines (LAPP), \\ CNRS-Universités Montpellier 1 et 2, Place Eugène Bataillon, \\ 34095 Montpellier Cedex 5, France
}

\begin{abstract}
Exchange of benzylidene ligand of commercially available Grubbs catalysts $\mathbf{1 a}$ or $\mathbf{1 b}$ with an appropriate soluble-polymer supported ligand leads to new boomerang type catalysts either of the Grubbs (3) or the Hoveyda type (4a or $\mathbf{4 b}$ ). These catalysts, supported on poly(ethylene glycol) (PEG), were fully characterized by solution NMR and MALDI mass spectrometry. They were tested in ring-closing metathesis (RCM), and ${ }^{1} \mathrm{H} N M R$ analysis provided key information concerning the recovery of the catalyst at the end of the reaction. While in the case of $\mathbf{3}$ the active ruthenium did not hook back to the ligand, catalysts $\mathbf{4 a}$ and $\mathbf{4 b}$ can be recovered and recycled. $\mathbf{4 b}$ owning a $\mathbf{N}$-heterocyclic carbene ligand is particularly active and was used in the parallel synthesis of cyclic amino esters.
\end{abstract}

\section{Introduction}

Ring-closing metathesis (RCM $)^{1-10}$ has become a very powerful and versatile technique in organic chemistry for the synthesis of cyclic structures mainly because of the development of ready to use ruthenium precatalysts such as $\mathbf{1 a}$ or $\mathbf{2} \mathbf{a}$, which are tolerant of a wide variety of functional groups. ${ }^{5,10}$ Recently more active catalysts such as $\mathbf{1 b}$ or $\mathbf{2} \mathbf{b}$ with a heterocyclic carbene ligand have been disclosed (Figure 1). ${ }^{11-18}$

The current challenge for catalysis in the perspective of industrial applications is the efficiency of the catalytic process and the ability to recycle the catalyst. Polymersupported catalysis has received recently increasing attention since this approach should facilitate purifica-

* Corresponding author. Fax: +33 (0) 4671448 66. E-mail: frederic@univ-montp2.fr.

(1) Schuster, M.; Blechert, S. Angew. Chem., Int. Ed. Engl. 1997, 36, 2036-2055.

(2) I vin, K. J . J . Mol. Catal. A: Chem. 1998, 133, 1-16.

(3) Randall, M. L.; Snapper, M. L. J . Mol. Catal. A: Chem. 1998 133, 29-40.

(4) Armstrong, S. K. J . Chem. Soc., Perkin Trans. 1 1998, 371-388.

(5) Grubbs, R. H.; Chang, S. Tetrahedron 1998, 54, 4413-4450.

(6) Fürstner, A. Top. Organomet. Chem. 1998, 1, 1-231.

(7) Trnka, T. N.; Grubbs, R. H. Acc. Chem. Res. 2001, 34, 18-29.

(8) Fürstner A. Angew. Chem., Int. Ed. 2000, 39, 3012-3043.

(9) Phillips, A. J .; Abell, A. D. Aldrichim. Acta 1999, 32, 75-90.

(10) Kingsbury, J . S.; Harrity, J . P. A.; Bonitatebus, P.J .; Hoveyda,

A. H.J . Am. Chem. Soc. 1999, 121, 791-799.

(11) Huang, J.; Stevens, E. D.; Nolan, S. P.; Peterson, J . L. J . Am. Chem. Soc. 1999, 121, 2674-2678.

(12) Scholl, M.; Trnka, T. N.; Morgan, J . P.; Grubbs, R. H. Tetrahedron Lett. 1999, 40, 2247-2250.

(13) Scholl, M.; Ding, S.; Lee, C. W.; Grubbs, R. H. Org. Lett. 1999 $1,953-956$

(14) Chatterjee, A. K.; Grubbs, R. H. Org. Lett. 1999, 1, 1751-1753.

(15) Chatterjee, A. K.; Grubbs, R. H. J . Am. Chem. Soc. 2000, 122, 3783-3784.

(16) Ackermann, L.; F ürstner, A.; Weskamp, T.; Kohl, F. J .; Herrmann, W. A. Tetrahedron Lett. 1999, 40, 4787-4790.

(17) Weskamp, T.; Kohl, F. J .; Hieringer, W.; Gleich, D.; Herrmann, W. A. Angew. Chem., Int. Ed. 1999, 38, 2417-2419.

(18) Garber, S. B.; Kingsbury, J . S.; Gray, B. L.; Hoveyda, A. H. J . Am. Chem. Soc. 2000, 122, 8168-8179.
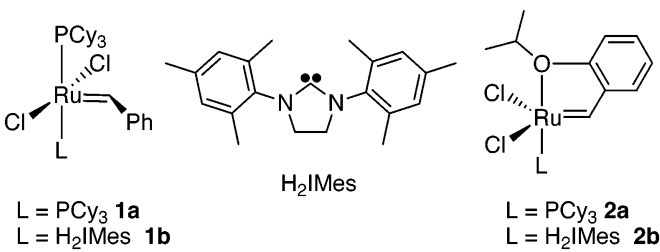

Figure 1. Grubbs' and Hoveyda's catalysts.

tion of the synthesized product as well as the recycling of the catalyst. ${ }^{19-25}$ For this purpose, a few synthetic and recycling studies on polymer-supported ruthenium precatalysts have been reported. ${ }^{26-37}$ Nevertheless most of these precatalysts are supported on an insoluble

(19) Clapham, B.; Reger, T. S.; J anda, K. D. Tetrahedron 2001, 57, 4637-4662.

(20) de Miguel, Y.J . Chem. Soc., Perkin Trans. 1 2000, 4213-4221.

(21) Leadbeater, N. E.; Marco, M. Chem. Rev. 2002, 102, 3217-3274.

(22) McNamara C. A.; Dixon, M. J .; Bradley, M. Chem. Rev. 2002, 102, 3275-3300.

(23) Barrett, A. G. M.; Hopkins, B. T.; Köbberling, J . Chem. Rev. 2002, 102, 3301-3324.

(24) Dickerson, T. J .; Reed, N. N.; J anda, K. D. Chem. Rev. 2002, 102, 3325-3344.

(25) Bergbreiter, D. E. Chem. Rev. 2002, 102, 3345-3384

(26) Yao, Q. W. Angew. Chem., Int. Ed. 2000, 39, 3896-3898.

(27) Nguyen, S. T.; Grubbs, R. H. J . Organomet. Chem. 1995, 497 195-200.

(28) Schürer, S. C.; Gessler, S.; Buschmann, N.; Blechert, S. Angew. Chem., I nt. Ed. 2000, 39, 3898-3901.

(29) Randl, S.; Buschmann, N.; Connon, S. J .; Blechert, S. Synlett 2001, 1547-1550.

(30) Connon, S. J .; Dunne, A. M.; Blechert, S. Angew. Chem., Int. Ed. 2002, 41, 3835-3838.

(31) Melis, K.; De Vos, D.; J acobs, P.; Verpoort, F. J . Mol . Catal. A: Chem. 2001, 169, 47-56.

(32) Ahmed, M.; Barrett, A. G. M.; Braddock, D. C.; Cramp, S. M.; Procopiou, P. A. Tetrahedron Lett. 1999, 40, 8657-8662.

(33) Ahmed, M.; Arnauld, T.; Barrett, A. G. M.; Braddock, D. C. Procopiou, P. A. Synlett 2000, 1007-1009.

(34) J afarpour, L.; Nolan, S. P. Org. Lett. 2000, 2, 4075-4078.

(35) Dowden, J .; Savovic, J . Chem. Commun. 2001, 37-38.

(36) Hultzsch, K. C.; J ernelius, J . A.; Hoveyda, A. H.; Schrock, R. R. Angew. Chem., Int. Ed. 2002, 41, 589-593.

(37) J afarpour, L.; Heck, M. P.; Baylon, C.; Lee, H. L.; Mioskowski, C.; Nolan, S. P. Organometallics 2002, 21, 671-679. 
polymer, which presents two main drawbacks. First, due to the heterogeneity of the support, access to the reactive site is very often reduced, hence resulting in poor catalysis. Second the structural information regarding this type of reaction is limited: while the ability of the catalyst to be recycled is easily assessed on a test experiment, structural analysis of the precatalyst before as well as after recovery at the end of the reaction requires less available technique with an insoluble polymer and was not reported. An alternative to insoluble supports is the use of a soluble polymer, which should facilitate the accessibility to reactive sites and reduce the problems of diffusion rate within the polymer as well as provide access to structural information using classical solution spectroscopic methods. ${ }^{38}$ The most widely used soluble polymer is poly(ethylene glycol) $(P E G)$. It is soluble in polar organic solvents and has the advantage of providing the possiblity of analyzing the supported moiety with classical solution NMR spectroscopy ${ }^{38}$ or mass spectrometry. ${ }^{39-43}$ Recovery of the supported material such as a catalyst is performed by precipitation in a nonpolar solvent followed by filtration. ${ }^{38,44-56}$ Consequently in the case of a PEGsupported RCM catalyst it is possible to characterize a supported precatalyst, to monitor the advancement of a reaction and the evolution of the catalyst during the course of a reaction, and finally to evaluate the ability of recovering the catalyst at the end of the reaction. The first example of PE G-supported RCM catalysts has been reported. ${ }^{26}$ This catalyst proved to be efficient in RCM reactions, and it had good recycling abilities. A different approach consisting in synthesizing a sol uble polymeric support by ring-opening metathesis polymerization has been described, and efficient ROMP-gel catalysts have been synthesized. ${ }^{30}$

(38) Gravert, D. J .; J anda, K. D. Chem. Rev. 1997, 97, 489-509.

(39) Sauvagnat, B.; Enjalbal, C.; Lamaty, F.; Lazaro, R.; Martinez, I.; Aubagnac, ] . L. Rapid Commun. Mass Spectrom. 1998, 12, 10341037.

(40) Nativel, F.; Enjalbal, C.; Lamaty, F.; Lazaro, R.; Martinez, J .; Aubagnac, J. L. Eur. Mass Spectrom. 1998, 4, 233-237.

(41) Enjal bal, C.; Sauvagnat, B.; Lamaty, F.; Lazaro, R.; Martinez, J .; Mouchet, P.; Roux, F.; Aubagnac, J. L. Rapid Commun. Mass Spectrom. 1999, 13, 1775-1781.

(42) Varray, S.: Aubagnac, I. L. : Lamaty, F . L azaro, R.; Martinez, J . Enjalbal, C. Analusis 2000, 28, 263-268.

(43) Enjalbal, C.; Lamaty, F.; Sanchez, P.; Suberchicot, E.; Ribière P.; Varray, S.; Lazaro, R.; Yadav-Bhatnagar, N.; Martinez, J .; Aubagnac, J.-L. Anal. Chem. 2003, 75, 175-184.

(44) Bolm, C.; Gerlach, A. Angew. Chem., Int. Ed. Engl. 1997, 36, $741-743$.

(45) Han, H. S.; J anda, K. D. J . Am. Chem. Soc. 1996, 118, 76327633.

(46) Han, H. S.; J anda, K. D. Tetrahedron Lett. 1997, 38, 15271530.

(47) Annunziata, R.; Benaglia, M.; Cinquini, M.; Cozzi, F.; Tocco, G. Org. Lett. 2000, 2, 1737-1739.

(48) Bergbreiter, D. E.; Osburn, P. L.; Liu, Y. S. J . Am. Chem. Soc. $1999,121,9531-9538$.

(49) Bergbreiter, D. E.; Osburn, P. L.; Wilson, A.; Sink, E. M. J . Am. Chem. Soc. 2000, 122, 9058-9064.

(50) Glos, M.; Reiser, O. Org. Lett. 2000, 2, 2045-2048

(51) Annunziata, R.; Benaglia, M.; Cinquini, M.; Cozzi, F.; Pitillo, M. J . Org. Chem. 2001, 66, 3160-3166.

(52) Loch, J. A.; Borgmann, C.; Crabtree, R. H. J . Mol. Catal. A: Chem. 2001, 170, 75-80.

(53) Guerreiro, P.; Ratovel omanana Vidal, V.; Genet, J . P.; Dellis, P. Tetrahedron Lett. 2001, 42, 3423-3426.

(54) Fan, Q. H.; Deng, G. J .; Chen, X. M.; Xie, W. C.; J iang, D. Z.;

Liu, D. S.; Chan, A. S. C. J. Mol. Catal. A: Chem. 2000, 159, 37-43.

(55) Fan, Q. H.; Deng, G. J .; Lin, C. C.; Chan, A. S. C. Tetrahedron: Asymmetry 2001, 12, 1241-1247. 6934.

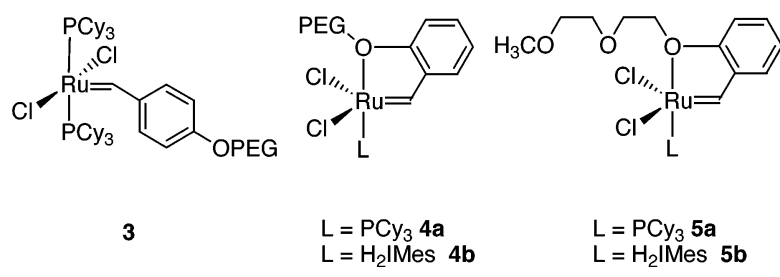

PEG-OH $=\mathrm{H}-\left(\mathrm{O}-\mathrm{CH}_{2}-\mathrm{CH}_{2}\right)_{n}-\mathrm{OH}$ with an average $\mathrm{MW}=3400$

Figure 2. Structure of polyoxygenated catalysts.

\section{Scheme 1. Synthesis of the Supported Ligands}
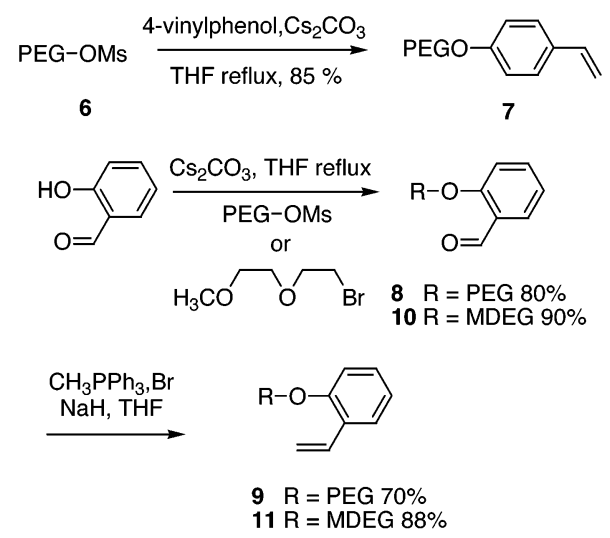

We present herein the synthesis and characterization of two efficient and novel PEG-supported catalysts. Their efficiency in ring-closing metathesis was assessed and compared to results obtained with a structurally similar nonsupported catalyst.

\section{Results and Discussion}

The catalysts that were evaluated are presented in Figure 2.

We designed two types of boomerang catalysts $18,26,29,30,32-35,37$ bearing a PEG-bound benzylidene ligand, the ether linkage being either para (catalyst 3) or ortho (catalysts $\mathbf{4 a}$ and $\mathbf{4 b}$ ) to the metal carbene group. Examples of catalyst using this ether linkage have been previously reported. ${ }^{29,35}$ Catalyst $\mathbf{3}$ is a Grubbs type catalyst. ${ }^{57}$ The vicinal oxygens of the polymer present in ortho position to the carbene in $\mathbf{4 a}$ or $\mathbf{4 b}$ may interact with the metal and provide a bidentate ligand. Consequently we can take advantage of the polymer structure to synthesize new catalysts and we can expect $\mathbf{4 a}$ and $\mathbf{4} \mathbf{b}$ to be Hoveyda type catalysts ${ }^{10,18}$ with a $\mathbf{R u}-\mathrm{O}$ interaction such as in $\mathbf{2 a}$ and $\mathbf{2 b}$. To evaluate the effect of the support in catalysts $\mathbf{4 a}$ and $\mathbf{4 b}$ and since we have shown that it could be detrimental in the case of PEG-supported RCM, 58 structurally similar catalysts $\mathbf{5 a}$ and $\mathbf{5 b}$ missing the polymer were also prepared.

The catalysts were easily accessible via suitable ligand exchange ${ }^{32}$ with the benzylidene of commercially available catalyst $\mathbf{1 a}$ or $\mathbf{1 b}$.

1. Synthesis of the Ligands. Syntheses of the ligands are described in Scheme 1. p-Pegylated-styrene 7 was synthesized by $\mathrm{O}$-alkylation of the corresponding

(57) Nguyen, S. T.; Grubbs, R. H.; Ziller, J . W. J . Am. Chem. Soc. 1993, 115, 9858-9859.

(58) Varray, S.; Gauzy, C.; Lamaty, F.; Lazaro, R.; Martinez, J . J . Org. Chem. 2000, 65, 6787-6790. 
Table 1. Characteristic ${ }^{1} \mathrm{H},{ }^{13} \mathrm{C}$, and ${ }^{31} \mathrm{P}$ Chemical Shifts of Ru Catalysts

\begin{tabular}{lccc}
\hline catalyst $^{\mathrm{a}}$ & ${ }^{1} \mathrm{H}(\mathrm{ppm})$ & ${ }^{13} \mathrm{C}(\mathrm{ppm})$ & ${ }^{31} \mathrm{P}(\mathrm{ppm})$ \\
\hline $\mathbf{1 a}$ & 20.02 & 294.72 & 36.61 \\
$\mathbf{1 b}$ & 19.16 & & 31.41 \\
$\mathbf{2 a}$ & 17.44 & 280.63 & 59.97 \\
$\mathbf{2 b}$ & 16.56 & 296.83 & \\
$\mathbf{3}$ & 19.50 & 280.79 & 36.63 \\
$\mathbf{4 a}$ & 17.40 & 278.35 & 60.95 \\
$\mathbf{4 b}$ & 16.50 & 292.95 & \\
$\mathbf{5 a}$ & 17.35 & 278.48 & 60.96 \\
$\mathbf{5 b}$ & 16.50 & 293.98 &
\end{tabular}

a NMR data for $\mathbf{1 a}, \mathbf{1 b}, \mathbf{2} \mathbf{a}$, and $\mathbf{2} \mathbf{b}$ were retrieved from the literature (refs $57,13,10,18$, respectively.)

Scheme 2. Synthesis of Various Catalysts by Ligand Exchange

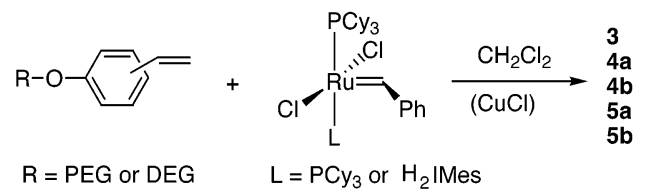

phenol with the mesylate of bifunctional PEG 3400 in the presence of $\mathrm{Cs}_{2} \mathrm{CO}_{3}$ as described in Scheme 1.47,52,59,60 For the ortho isomer, alkylation of PEG-OMs with salicylal dehyde foll owed by Wittig ol efination ${ }^{61}$ yielded the corresponding ligand 9. A similar synthesis was performed to obtain $\mathbf{1 1}$ starting from 1-bromo-2-(2methoxyethoxy)ethane. At each step the PE G-supported molecule was precipitated in ether, filtered, and characterized by $\mathrm{IR},{ }^{1} \mathrm{H}$ and ${ }^{13} \mathrm{C} \mathrm{NMR}$, and $\mathrm{ESI}$-mass spectrometry.

2. Synthesis and Characterization of the Catalysts. Ligand exchange with the suitable catalyst 1a or 1b gave access to catalysts 3-5 (Scheme 2). The structure of the catalysts was ascertained by solution NMR and MALDI-Tof mass spectrometry. ${ }^{41}$

Catalyst $\mathbf{3}$ was synthesized by reacting $\mathbf{l a}$ with ligand 7. The reaction was monitored by ${ }^{1} \mathrm{H}$ NMR following the disappearance of the ethylene proton of $\mathbf{7}$ and the appearance of the benzylidene proton of $\mathbf{3}$. The values of the characteristic NMR chemical shifts for the metalattached methine group are reported in Table 1. When a phosphine ligand is present, the value of the corresponding ${ }^{31} \mathrm{P}$ NMR chemical shift is given. F or comparison, values for complexes $\mathbf{1} \mathbf{a}, \mathbf{b}$ and $\mathbf{2} \mathbf{a}, \mathbf{b}$ reported in the literature are also given. Two equivalents of $\mathbf{l a}$ were necessary to complete the reaction within $16 \mathrm{~h}$ at room temperature in $\mathrm{CH}_{2} \mathrm{Cl}_{2}$. Similarly catalysts $\mathbf{4 a}$ and $\mathbf{4 b}$ were synthezised. In this case $48 \mathrm{~h}$ were needed for completion of the reaction. It is noteworthy that in the case of $\mathbf{4 b}$, when the reaction was analyzed after $16 \mathrm{~h}$, before completion, the presence of an intermediate complex was observed by ${ }^{1} \mathrm{H}$ NMR. This complex was characterized by a chemical shift of the benzylidene proton at 17.75 ppm in $\mathrm{CD}_{2} \mathrm{Cl}_{2}$, corresponding to structure $\mathbf{1 2}$ (Figure 3), in agreement with literature data. ${ }^{62}$ For the synthesis of PEG-supported catalysts $\mathbf{4 a}$ and

(59) Ladd, D. L.; Henrichs, P. M. Synth. Commun. 1998, 28, 41434149.

(60) Wentworth, A. D.; Wentworth, P.; Mansoor, U. F.; J anda, K. D. Org. Lett. 2000, 2, 477-480.

(61) Chang, S.; Grubbs, R. H. J . Org. Chem. 1998, 63, 864-866.

(62) Gessler, S.; Randl, S.; Blechert, S. Tetrahedron Lett. 2000, 41 , 9973-9976.

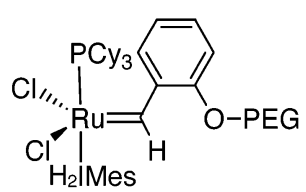

Figure 3. I ntermediate complex 12 observed by ${ }^{1} \mathrm{H}$ NMR.

Table 2. Mass Increments between Native and F unctionalized PE G

\begin{tabular}{cccc}
\hline catalyst & $\begin{array}{c}\text { calcd mass increment } \\
\text { from PEG } \mathrm{PE}_{3400}(\Delta \mathrm{m})\end{array}$ & theoretical peak & $\begin{array}{c}\text { measured } \\
\text { peak }\end{array}$ \\
\hline $\mathbf{4 a}$ & 1078 & $3938.3\left(\mathrm{n}=64, \mathrm{Na}^{+}\right)$ & 3937.7 \\
& & $4290.8\left(\mathrm{n}=72, \mathrm{Na}^{+}\right)$ & 4290.3 \\
& & $4511.0\left(\mathrm{n}=77, \mathrm{Na}^{+}\right)$ & 4510.5 \\
4b & \multirow{2}{*}{1132} & $3788.2\left(\mathrm{n}=59, \mathrm{~K}^{+}\right)$ & 3788.1 \\
& & $4052.5\left(\mathrm{n}=62, \mathrm{~K}^{+}\right)$ & 4052.2 \\
& & $4316.8\left(\mathrm{n}=71, \mathrm{~K}^{+}\right)$ & 4316.4
\end{tabular}

4b, the use of $\mathrm{CuCl}^{63}$ did not accelerate the ligand exchange reaction.

In the case of catalysts $\mathbf{5 a}$ and $\mathbf{5 b}, \mathbf{1} \mathbf{a}$ and $\mathbf{1 b}$ (respectively) were first reacted with $\mathrm{CuCl}$ to facilitate removal of the phosphine ligand before its replacement by the oxygen ligands. ${ }^{63}$ Addition of ligand $\mathbf{1 1}$ resulted in the formation of $\mathbf{5 a}$ and $\mathbf{5 b}$ (respectively), as it can be checked by ${ }^{1} \mathrm{H}$ NMR of the crude mixture. Nevertheless $5 \mathrm{a}$ had a tendency to degrade on column chromatography and was obtained as a 9:1 mixture of catalyst $\mathbf{5 a / l i g a n d ~} \mathbf{1 1}$. 5b proved to be more stable, and no degradation was observed in the same conditions. It has to be noted that contrary to the synthesis of the PEGsupported version of the catalysts (4a and $\mathbf{4 b}$ ), $\mathbf{C u C l}$ was needed to avoid degradation before complete ligand exchange and total conversion. In the case of $\mathbf{4 a}$ and 4b (respectively) using only an excess of starting catalyst was sufficient.

As a representative example, ${ }^{1} \mathrm{H}$ NMR and MALDITOF spectra of catalyst $\mathbf{4 b}$ are shown in Figures 4 and 5. We had shown previously that MALDI mass spectrometry could be used to control a multistep organic synthesis supported on a soluble polymer. ${ }^{41}$ The spectrum reported in Figure 4 is characteristic of catalyst $\mathbf{4 b}$ since ions extracted from the polymer distribution confirm the catalyst structure. I ndeed one can calculate the mass increment induced by grafting the organometallic complex on the native PEG-OH. This corresponds to an increment of $1132=2 \times(567-1)$. The calculated theoretical values and the observed peak values for three ions ( $n=59,62$, and 71$)$ are reported in Table 2 . The perfect match within the precision of MALDI mass spectrometry between these values (and which can be extended to other ions) ascertains the atomic composition of the catalyst.

Figure 5 shows the ${ }^{1} \mathrm{H}$ NMR spectrum of $\mathbf{4 b}$ in $\mathrm{CD}_{2^{-}}$ $\mathrm{Cl}_{2}$. The signals of the different protons present in the molecule were assigned. The characteristic benzylidene proton is found at $16.52 \mathrm{ppm}$.

3. Catalyst Activity and Recycling. 3.1. Results. The activities of the different catalysts were tested on the ring-closing metathesis (RCM) of two substrates: tosyl diallylamine $\mathbf{1 3}$ and $\mathrm{N}$-allyl allylglycine $\mathbf{1 5}$. The rebinding of the catalyst was assessed as foll ows: at the end of the reaction, the cyclized product was recovered

(63) Dias, E. L.; Nguyen, S. T.; Grubbs, R. H. J . Am. Chem. Soc 1997, 119, 3887-3897. 


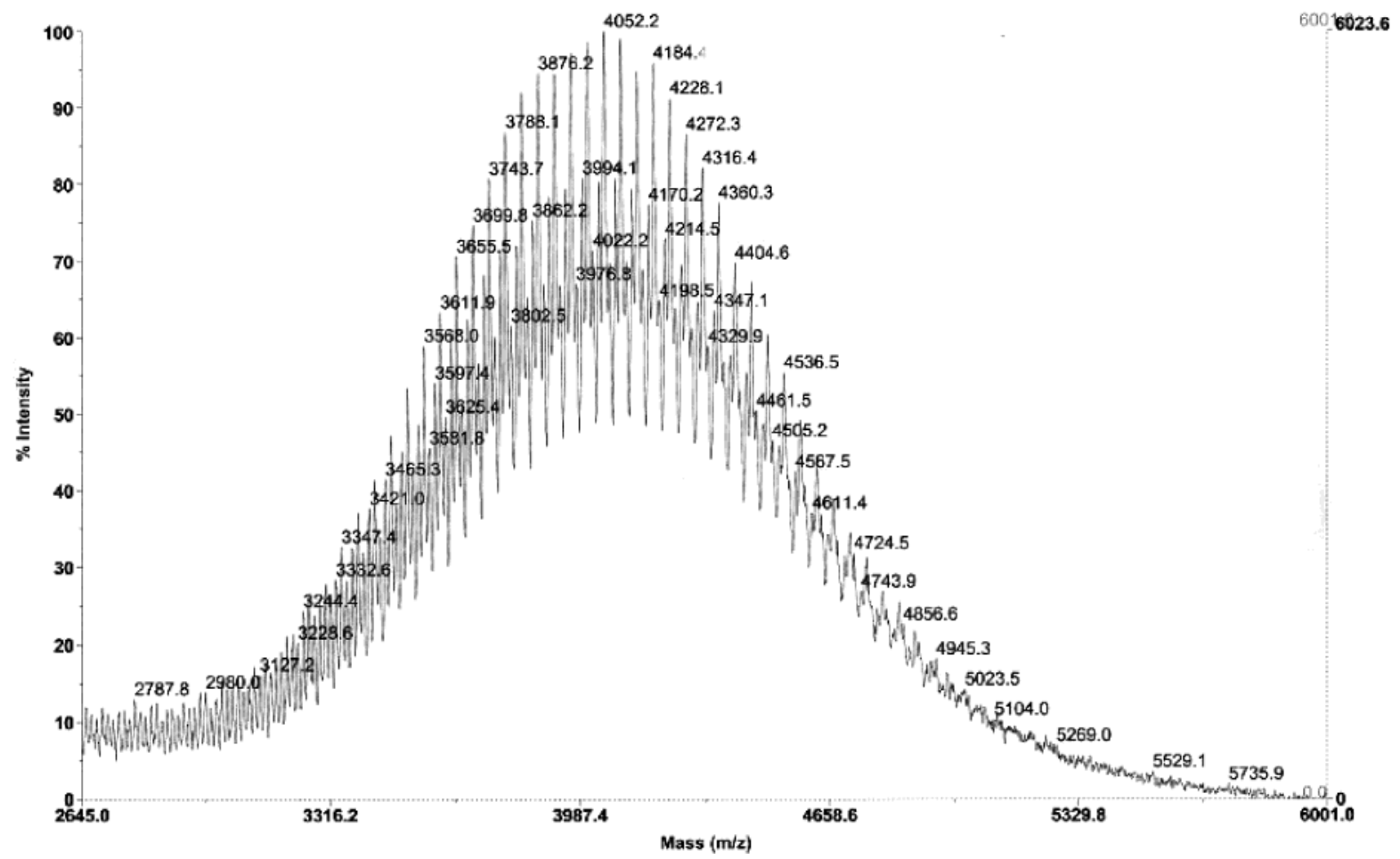

Figure 4. MALDI-T of mass spectrum of compound $\mathbf{4 b}$ in 2-cyano-4-hydroxycinnamic acid.

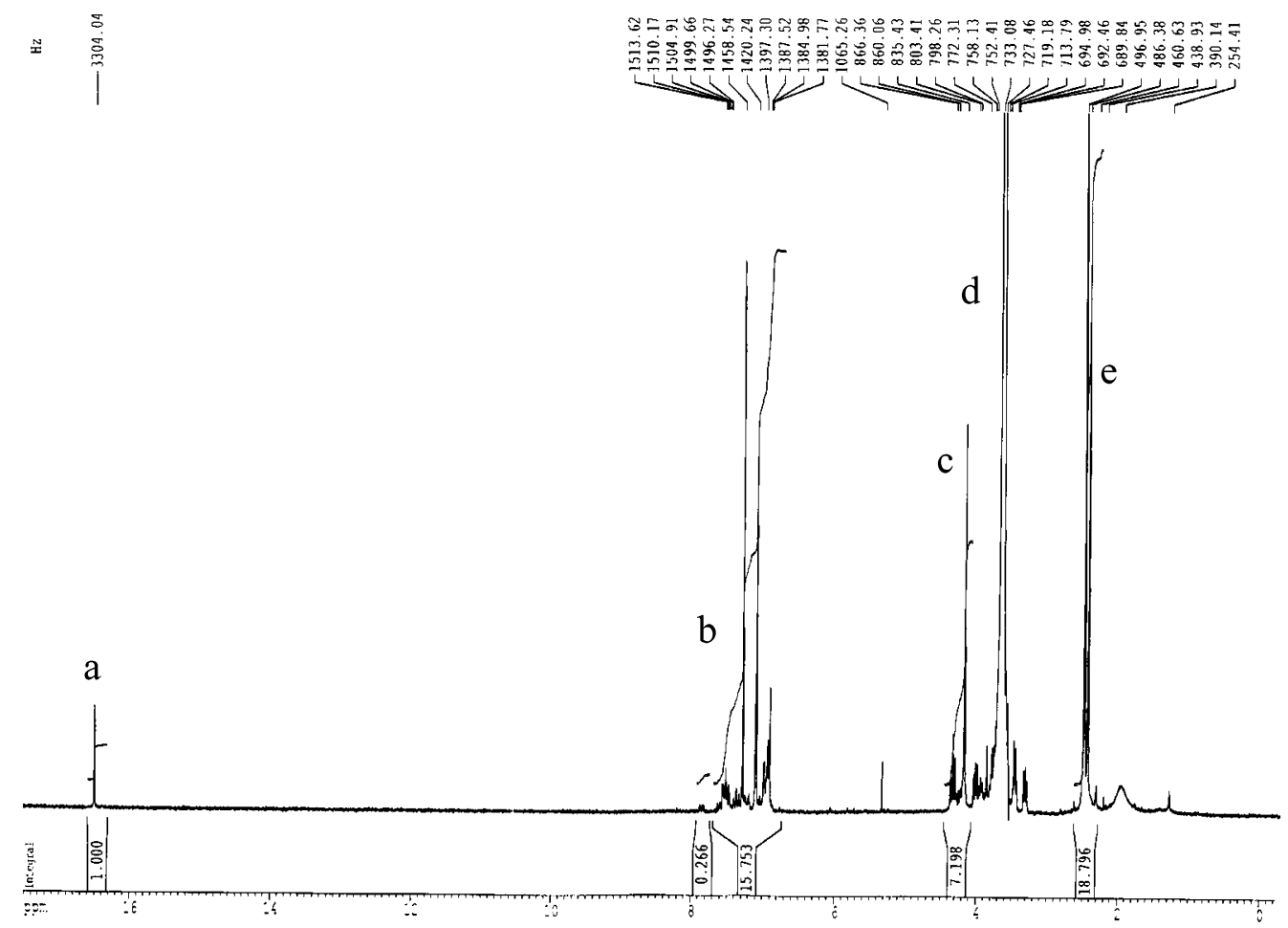

Figure 5. ${ }^{1} \mathrm{H}$ NMR spectrum of compound $\mathbf{4 b}$ : (a) carbenic proton, (b) aromatic protons, (c) imidazole methylene protons, (d) methylene PEG protons, (e) methyl protons.

after precipitation and filtration. The precipitate was analyzed by ${ }^{1} \mathrm{H}$ NMR. The integration ${ }^{10}$ of the alkylidene proton for the metal-occupied product and of the proton in $\alpha$ position to styrene for the metal-vacant product gave the proportion of rebinding.

Catalyst $\mathbf{3}$ was tested in the cyclization of tosyldiallylamine by using $5 \mathrm{~mol} \%$ of catalyst (10 mol \% Ru). The cyclization was complete within $15 \mathrm{~min}$, and the cyclized product $\mathbf{1 4}$ was obtained in $72 \%$ yield after precipitation in $\mathrm{Et}_{2} \mathrm{O}$ and filtration, proving the efficiency of $\mathbf{3}$ in a RCM reaction. Nevertheless ${ }^{1} \mathrm{H}$ NMR analysis of the precipitate showed the complete disappearance of the signal at $19.50 \mathrm{ppm}$, corresponding to the proton borne by the metal carbene. Only the vinyl ligand could be detected in the precipitate. Consequently we can conclude that the catalyst cannot be recovered and recycled after reaction since it did not react with the ligand. 
Table 3. Recycling Reactions of Catalyst 4a

\begin{tabular}{lccccc}
\hline & & & \multicolumn{3}{c}{ composition of the precipitate (conditions 3) (\%) } \\
\cline { 3 - 6 } cycle & conversion (conditions 2) & conversion (conditions 3) & 4a & $\mathbf{8}$ & $\mathbf{9}$ \\
\hline 1 & 90 & 98 & 25 & 43 & 32 \\
2 & 38 & 63 & 12 & 49 & 39 \\
& & Table 4. Recycling Reactions of Catalyst 4b & \\
\hline
\end{tabular}

\begin{tabular}{lcccccc}
\hline & & & & \multicolumn{2}{c}{$\begin{array}{c}\text { composition of the precipitate } \\
\text { (conditions 1) (\%) }\end{array}$} \\
\cline { 3 - 6 } cycle & $\begin{array}{c}\text { conversion } \\
\text { (conditions 1) }\end{array}$ & $\begin{array}{c}\text { conversion } \\
\text { (conditions 2) }\end{array}$ & $\begin{array}{c}\text { conversion } \\
\text { (conditions 3) }\end{array}$ & $\mathbf{4 b}$ & $\mathbf{8}$ & $\mathbf{9}$ \\
\hline 1 & 100 & 100 & 100 & 57 & 30 & 13 \\
2 & 100 & 93 & 100 & 34 & 39 & 28 \\
3 & 85 & 90 & 85 & 34 & 28 & 38 \\
4 & 80 & 85 & 85 & 27 & 38 & 36 \\
5 & 80 & 85 & 80 &
\end{tabular}

a Figures are given within the error of measurement by ${ }^{1} \mathrm{H}$ NMR.

Catalysts $\mathbf{4 a}$ and $\mathbf{4 b}$ were tested on the same reactions described previously (Tables 3 and 4). Preliminary results on those systems showed that both of the catalysts would perform the RCM reaction. In these cases the reaction was slower than in the case of $\mathbf{3}(2 \mathrm{~h}$ instead of $\mathbf{1 5} \mathbf{~ m i n}$ ). In the case of $\mathbf{4 a}$ when the precipitate was analyzed by ${ }^{1} \mathrm{H}$ NMR after precipitation and filtration at the end of the reaction, the characteristic signal at $17.40 \mathrm{ppm}$ for $\mathbf{4 a}$ was present, confirming the recovery of the catalysts (al beit not total). To investigate in more detail this reaction and evaluate the recycling, we set up a time limit ( $2 \mathrm{~h}$ for conditions $1,2 \mathrm{~h}$ for conditions 2, $2 \mathrm{~h}$ for conditions 3 ) to assess conversion of starting materials to product and to analyze the PEGsupported molecules. This study (Tables 3 and 4 ) was easily performed on a parallel manual synthesizer.

With catalyst 4a, for conditions 2 and 3, the catalytic activity dropped dramatically after the first cycle. These results can be correlated to the ${ }^{1} \mathrm{H} N \mathrm{NMR}$ analysis of the mixture of PEG-supported compounds obtained after the reaction. Indeed after two cycles only $12 \%$ of the ruthenium methylidene had rebound on theligand. The other components of the mixture were the free vinyl ligand $\mathbf{9}$ and supported salicylal dehyde $\mathbf{8}$.

In the case of $\mathbf{4 b}$, in sharp contrast, the recovery was more efficient ( $27 \%$ at the fifth cycle), and a high catalytic activity was retained even after five cycles.

3.2. Discussion. The result obtained with catalyst $\mathbf{3}$ was rather striking compared to the data in the literature concerning this type of supported catalyst on an insoluble polymer. In many cases, the conclusion that a catalyst reacted back on a vinyl ligand and that it can be used again is drawn from the fact that subsequent runs with the same supported catalyst can be performed with some catalytic activity. Indeed literature results in the solid phase supported boomerang precatalysts tend to conclude in the absence of structural information that the catalyst can be recycled, $, 32-35,37$ that additives such as 1-hexene improve the recycling by increasing the lifetime of the methylidene species, and that a consequence of the recycling, leaching of ruthenium in solution, is dramatically reduced. 32,33 One may hypothesize that in the case of an insoluble polymer the catalytic activity found in subsequent runs may arise from metal carbenes borne by less accessible sites, which can be released in solution in a second or third run. In some cases the use of additives such as 1-hexene is claimed to increase the lifetime of the methylidene complex, which can then hook back onto the polymer. These additives could also help the release of the less accessible methylidene-Ru sites from the polymer to the solution, which would translate to further catalytic activity. One has to note al so that usually for insoluble catalysts a ligand excess is used which could drive the reaction to the recovery of some carbenes. Finally one explanation for the decrease of leaching of $\mathrm{Ru}$ in the reaction medium at the end of the reaction could be that it is more an adsorption phenomenon on the polymer rather than a true recycling.

In sharp contrast, $\mathbf{4 b}$ exhibited a high activity after four runs, in agreement with the recovery of the metal carbene species on the polymer. The competing pathway with the reaction of the metal carbene species with the supported ligand is the decomposition of the carbene. As it has already been pointed out, ${ }^{11-18}$ this decomposition was inferior with a $\mathrm{N}$-heterocyclic carbene ruthenium complex (4b) than with a phosphine complex (4a).

Compound $\mathbf{8}$ originates probably from the oxidation of the metal-carbene species from the presence of oxygen in the reaction mixture ${ }^{57,64}$ Starting from a thoroughly degassed medium did not reduce the oxidation process. Most likely the oxophilicity of the PEG concurs in retaining the oxygen on the polymer backbone.

For the sake of comparison catalyst $\mathbf{5 b}$ was tested on the cyclization of tosyl diallylamine (conditions 1), and the expected product was synthesized in high yield. ${ }^{1} \mathrm{H}$ NMR analysis of the crude mixture revealed that $\mathbf{5 b}$ was not recycled. Nevertheless no oxidation product was present. This confirms that the oxidation of the ligand occurred with the presence of the polymer independently from the reaction conditions. If the reactivity of $\mathbf{5 b}$ and $\mathbf{4 b}$ was si milar at least in reaction conditions 1 , it seems that in $\mathbf{4} \mathbf{b}$ the presence of the bidentate complexation of the polymer-supported phenol provided further stability to the catalyst for better recovery. After cyclization, reaction with the methylidene complex rather than decomposition occurred. In this case and contrary to the results we observed previously, ${ }^{58}$ the chelating effect of PEG did not inhibit the RCM but rather provided additional stability to $\mathbf{4 b}$.

\section{Application to the Synthesis of Cyclic Ami-}

(64) Qian, Y.-L.; Chen, B.; J in, J .-T.; Huang, J .-L. Acta Chim. Sin. 2000, 58, 1050-1052. 
Scheme 3. Test Reactions for Recycling
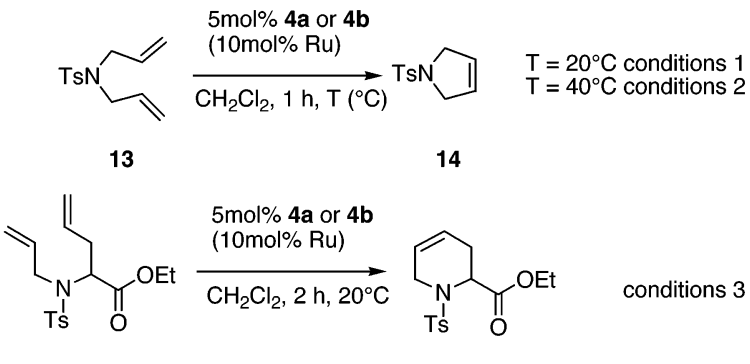

15

16

Scheme 4. Synthesis of Cyclic $\alpha$-Aminoesters

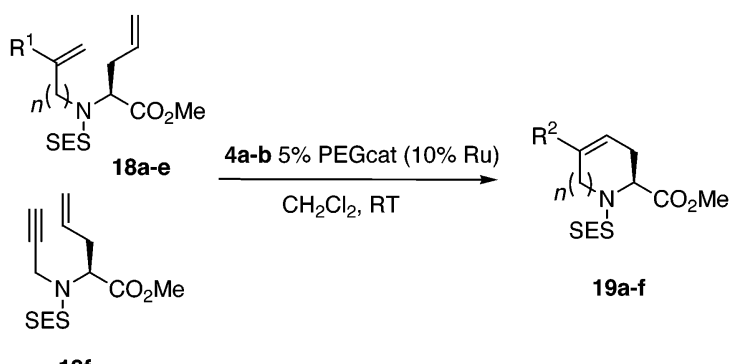

$18 f$

Scheme 5. Synthesis of Carboxy Pyrroline 21

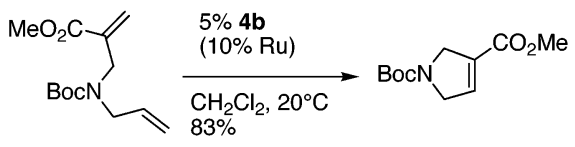

20

21

Table 5. Ring-Closing Metathesis of $\alpha$-Aminoesters by Supported Catalysts

\begin{tabular}{lllllc} 
entry & \multicolumn{1}{c}{$\mathrm{R}^{1}$} & $\mathbf{1 8}$ & $\mathrm{n}$ & \multicolumn{1}{c}{$\mathrm{R}^{2}$} & yield of $\mathbf{1 9}(\%)$ \\
\hline 1 & $\mathrm{H}$ & $\mathbf{a}$ & 1 & $\mathrm{H}$ & 91 \\
2 & $\mathrm{H}$ & $\mathbf{b}$ & 2 & $\mathrm{H}$ & 95 \\
3 & $\mathrm{H}$ & $\mathbf{c}$ & 3 & $\mathrm{H}$ & 93 \\
4 & $\mathrm{CH}_{3}$ & d & 1 & $\mathrm{CH}_{3}$ & 87 \\
$5^{\mathrm{a}}$ & $\mathrm{CO}_{2} \mathrm{Me}$ & $\mathbf{e}$ & 1 & $\mathrm{CO}_{2} \mathrm{Me}$ & 86 \\
6 & & $\mathbf{f}$ & 1 & $\mathrm{CH}=\mathrm{CH}_{2}$ & 89
\end{tabular}

a Catalyst $\mathbf{4 b}$ was used.

noesters. Having in hand the catalysts $\mathbf{4 a}$ and $\mathbf{4 b}$, they were used in the parallel synthesis of various cyclic aminoesters. For the $\alpha$-amino esters, the diversity arose from the alkylation step of a N-SES-protected allyl glycine with different alkylating agents in the presence of $\mathrm{K}_{2} \mathrm{CO}_{3}$ to yield several diene systems $18 \mathbf{a}-\mathbf{f}$. The reactions were performed in parallel on a manual synthesizer by reaction of the substrate in $\mathrm{CH}_{2} \mathrm{Cl}_{2}$ in the presence of $5 \mathrm{~mol} \%$ of $\mathbf{4 a}$ or $\mathbf{4 b}$ (Scheme 4 ).

After completion, the reaction mixture was transferred to ether for precipitation followed by filtration. The filtrate was evaporated, and column chromatography (to remove the small amount of Ru that had leached in the vessel) provided the cyclic products $19 a-\mathbf{f}$ in excellent yields (Table 5).

Five, six, and seven-membered rings could be obtained in good yield (entries 1-3). A substituted sixmembered ring could be formed either by diene (entries $4,5)$ or enyne ring-closing metathesis (entry 6). Remarkably, catalyst $\mathbf{4 b}$ was active enough to ensure cyclization of a substrate containing substituted electron- poor ol efins ${ }^{65-67}$ such as $\mathbf{2 0}$. This method provided an original access to the carboxy pyrroline $\mathbf{2 1}$ (Scheme 5).

\section{Conclusion}

A novel efficient boomerang catalyst supported on a soluble polymer was synthesized and characterized. The analysis possibilities inherent to the presence of a soluble polymer provided information on the recycling capacities of the catalyst: while the activity remained high, the return of the metal on the supported ligand was not total. Ring-closing metathesis, including the cyclization of electron-deficient olefins, provided an efficient access to cyclic amino esters.

\section{Experimental Section}

General Remarks. All reagents including poly(ethylene glycol ) 3400 were obtained from Aldrich Chemical Co. and used without purification. ${ }^{1} \mathrm{H}$ and ${ }^{13} \mathrm{C} N \mathrm{NMR}$ analyses were performed respectively with 200 and $400 \mathrm{MHz}$ NMR spectrometers. I nfrared spectra were recorded by diffuse reflectance or by transmittance as a microcup of $\mathrm{KBr}$ or by transmittance in $\mathrm{KBr}$ salt plates. Mass spectra (el ectrospray ionization mode, ESIMS) were recorded on a Platform II (Micromass, Manchester, U.K.) quadrupole mass spectrometer fitted with an electrospray interface. We report the mass spectrometry for bifunctional PEG 3400. The mass spectrometer was calibrated in the positive- and negative-ion ESI mode. The samples were dissolved in $\mathrm{H}_{2} \mathrm{O} / \mathrm{CH}_{3} \mathrm{CN}$ (50/50 v/v). Multiprotonated and multicationized ions were recovered in the positive and negative mode. PEG 3400 supported molecules appeared as distributions corresponding to charge states ranging from +2 to +5 , and oligomers between $n=74$ and $n=88$ were detected. Only two significant peaks were reported, and we used the increment of mass between the product and the PEG 3400 to confirm the spectrum. Correlations between the calculated and measured values were observed in both of the states considered. MALDI-TOF mass spectra were recorded on a Voyager DE-STR (Applied Biosystems) spectrometer equipped with electrostatic reflector and delayed extraction devices. $\alpha$-Cyanohydroxycinnamic acid was used as matrix. The compound under study and the matrix were dissolved in water/acetonitrile (1:1) at a concentration of $10 \mathrm{mg} / \mathrm{mL}$. Five microliters of each solution was mixed, and ions were generated by laser desorption at $337 \mathrm{~nm}$. Recycling test reactions and parallel RCM of aminoesters were performed on an Argonaut Technologies Quest 210 manual synthesizer.

Di $\left[R \mathrm{RCl}_{2}\left(\mathrm{PC}_{3}\right)\right.$ (=CHPh-p-0)]-PEG (3). $\mathrm{RuCl}_{2}\left(\mathrm{PCy}_{3}\right)_{2}=$ CHPh 1a $(0.091 \mathrm{~g}, 0.111 \mathrm{mmol})$ was added to a solution of 7 $(0.1 \mathrm{~g}, 0.028 \mathrm{mmol})$ in $10 \mathrm{~mL}$ of anhydrous $\mathrm{CH}_{2} \mathrm{Cl}_{2}$. The mixture was stirred at room temperature for $16 \mathrm{~h}$, then precipitated twice in ether to yield $0.13 \mathrm{~g}(92 \%)$ of the title compound as a gray powder: ${ }^{1} \mathrm{H}$ NMR $\left(\mathrm{CD}_{2} \mathrm{Cl}_{2}, \mathrm{Me}_{4} \mathrm{Si}\right) \delta 1.10$ $2.00(\mathrm{~m}, 120 \mathrm{H}), 2.60(\mathrm{sl}, 12 \mathrm{H}), 3.50-3.70(\mathrm{sl}, \sim 310 \mathrm{H}), 4.20$ $(\mathrm{m}, 4 \mathrm{H}), 6.85(\mathrm{~d}, \mathrm{~J}=8.5 \mathrm{~Hz}, 4 \mathrm{H}), 8.45(\mathrm{~d}, \mathrm{~J}=8.5 \mathrm{~Hz}, 4 \mathrm{H})$, 19.50 (s, $2 \mathrm{H})$; ${ }^{11} \mathrm{P} \mathrm{NMR}\left(\mathrm{CD}_{2} \mathrm{Cl}_{2}, \mathrm{Me} \mathrm{e}_{4} \mathrm{Si}\right) \delta 36.63 ;{ }^{13} \mathrm{C} \mathrm{NMR}$ $\left(\mathrm{CD}_{2} \mathrm{Cl}_{2}, \mathrm{Me}_{4} \mathrm{Si}\right) \delta 26.94,28.23(\mathrm{t}, \mathrm{J} \mathrm{cP}=18.5 \mathrm{~Hz}), 29.99,32.37$ $(\mathrm{t}, \mathrm{J} \mathrm{CP}=36.0 \mathrm{~Hz}), 61.94,68.02,69.83,70.89,72.92,114.45$, $134.22,148.27,159.62,280.79$.

Di $\left[\mathrm{RuCl}_{2}\left(\mathrm{PCy}_{\mathbf{3}}\right)\right.$ (=CHPh-o-0)]-PEG (4a). $\mathrm{RuCl}_{2}\left(\mathrm{PCy}_{3}\right)_{2}=$ $\mathrm{CHPh}$ la $(0.1 \mathrm{~g}, 0.122 \mathrm{mmol})$ was added at room temperature to a solution of $9(0.1 \mathrm{~g}, 0.028 \mathrm{mmol})$ in $10 \mathrm{~mL}$ of $\mathrm{CH}_{2} \mathrm{Cl}_{2}$. The reaction was stirred at $20^{\circ} \mathrm{C}$ for $48 \mathrm{~h}$. The product was

(65) Hyldtoft, L.; Madsen R. J . Am. Chem. Soc. 2000, 122, 84448452

(66) Kirkland, T. A.; Grubbs, R. H. J . Org. Chem. 1997, 62, 73107318

(67) Varray, S.; Lazaro, R.; Martinez, J .; Lamaty, F. Eur. J . Org. Chem. 2002, 2308-2316. 
precipitated twice in ether to yield $0.120 \mathrm{~g}(95 \%)$ of the title compound as a gray powder: IR cm $\mathrm{cm}^{-1} 3054$ (s), 2306 (w), 1265 (s), 1101 (s); ${ }^{1} \mathrm{H}$ NMR $\left(\mathrm{CD}_{2} \mathrm{Cl}_{2}, \mathrm{Me}_{4} \mathrm{Si}\right) \delta 1.20-2.45(\mathrm{~m}, 60 \mathrm{H})$, $3.55-3.75(\mathrm{sl}, \sim 310 \mathrm{H}), 4.25\left(\mathrm{t}, \mathrm{J}_{1}=4.5 \mathrm{~Hz}, 4 \mathrm{H}\right), 4.75\left(\mathrm{t}, \mathrm{J}_{1}=\right.$ $4.5 \mathrm{~Hz}, 4 \mathrm{H}), 7.20\left(\mathrm{t}, \mathrm{J}_{2}=8.0 \mathrm{~Hz}, 2 \mathrm{H}\right), 7.35\left(\mathrm{~d}, \mathrm{~J}_{3}=8.5 \mathrm{~Hz}, 2\right.$ $\mathrm{H}), 7.65-7.75(\mathrm{~m}, 4 \mathrm{H}), 17.40\left(\mathrm{~d}, \mathrm{~J}_{4}=4.5 \mathrm{~Hz}, 2 \mathrm{H}\right)$; ${ }^{31} \mathrm{P}$ NMR $\left(\mathrm{CD}_{2} \mathrm{Cl}_{2}, \mathrm{Me}_{4} \mathrm{Si}\right) \delta$ 60.95. ${ }^{13} \mathrm{C} \mathrm{NMR}\left(\mathrm{CD}_{2} \mathrm{Cl}_{2}, \mathrm{Me}_{4} \mathrm{Si}\right) \delta 26.66$, $28.08,28.19,30.33,35.77,36.02,69.98,70.10,70.96,71.13$, $113.56,122.72,123.85,130.15,143.84,154.85,278.35$; MS (Maldi) $\mathrm{m} / \mathrm{z} \mathrm{n}=64,3938.3\left(1 \mathrm{Na}^{+}\right)$.

Di[RuCl ${ }_{2}\left(\mathrm{H}_{2}\right.$ IMes)(=CH-o-O)]PEG (4b). $\mathrm{RuCl}_{2} \mathrm{PCy}_{3} \mathrm{H}_{2-}$ I $\mathrm{Mes}=\mathrm{CHPh} \mathbf{1 b}(0.155 \mathrm{~g}, 0.183 \mathrm{mmol})$ was added to a solution of $9(0.300 \mathrm{~g}, 0.083 \mathrm{mmol})$ in $30 \mathrm{~mL}$ of $\mathrm{CH}_{2} \mathrm{Cl}_{2}$. The reaction was stirred at $40{ }^{\circ} \mathrm{C}$ for $48 \mathrm{~h}$. The residue was precipitated twice in ether to yield $0.354 \mathrm{~g}(94 \%)$ of the title compound as a green powder: IR cm $\mathrm{cm}^{-1} 3054(\mathrm{~m}), 2306(\mathrm{w}), 1687(\mathrm{~m}), 1348$ (m), 1104 (s); ${ }^{1} \mathrm{H}$ NMR $\left(\mathrm{CD}_{2} \mathrm{Cl}_{2}, \mathrm{Me} \mathrm{e}_{4} \mathrm{Si}\right) \delta 2.50(\mathrm{~s}, 12 \mathrm{H}), 2.50$ $(\mathrm{s}, 24 \mathrm{H}), 3.55-3.75(\mathrm{sl}, \sim 310 \mathrm{H}), 4.20(\mathrm{~s}, 8 \mathrm{H}), 4.30\left(\mathrm{t}, \mathrm{J}_{1}=\right.$ $6.0 \mathrm{~Hz}, 4 \mathrm{H}), 6.95-7.05(\mathrm{~m}, 6 \mathrm{H}), 7.10(\mathrm{~s}, 8 \mathrm{H}), 7.55-7.65(\mathrm{~m}$, $2 \mathrm{H}), 16.50(\mathrm{~s}, 2 \mathrm{H}) ;{ }^{13} \mathrm{C} N M R\left(\mathrm{CD}_{2} \mathrm{Cl}_{2}, \mathrm{Me}_{4} \mathrm{Si}\right) \delta 20.56,22.41$, $52.87,69.06,69.79,71.79,113.99,123.48,124.58,127.72$, 129.83, 130.73, 131.00, 140.00, 145.68, 154.53, 211.93, 292.95; MS (Maldi) $\mathrm{m} / \mathrm{z} \mathrm{n}=62,4052.2\left(1 \mathrm{~K}^{+}\right)$.

$\mathbf{R u C l}_{2}$ (=CH-o-OMDE G)PCy $\mathbf{3}$ (5a). CuCl $(0.010 \mathrm{~g}, 0.097$ $\mathrm{mmol}$ ) was added at room temperature to a solution of $\mathrm{RuCl}_{2^{-}}$ $(=\mathrm{CHPh})\left(\mathrm{PCy}_{3}\right)_{2} \mathbf{l a}(0.08 \mathrm{~g}, 0.097 \mathrm{mmol})$ in $2 \mathrm{~mL}$ of $\mathrm{CH}_{2} \mathrm{Cl}_{2}$. The reaction was stirred for $15 \mathrm{~min}$, then 11 (0.022 g, 0.097 mmol) was added. The mixture was stirred at $20{ }^{\circ} \mathrm{C}$ for $3 \mathrm{~h}$. The solvent was evaporated and the residue was purified by chromatography [eluent: hexane/EtOAc, 9:1] to yield $0.047 \mathrm{~g}$ (72\%) of the title compound al ong with $10 \%$ of compound $\mathbf{1 1}$ : ${ }^{1} \mathrm{H}$ NMR $\left(\mathrm{CD}_{2} \mathrm{Cl}_{2}, \mathrm{Me}_{4} \mathrm{Si}\right) \delta 1.25-2.45(\mathrm{~m}, 33 \mathrm{H}), 3.40(\mathrm{~s}, 3 \mathrm{H})$, $3.55-3.65(\mathrm{~m}, 2 \mathrm{H}), 3.75-3.80(\mathrm{~m}, 2 \mathrm{H}), 4.25\left(\mathrm{t}, \mathrm{J}_{1}=4.5 \mathrm{~Hz}\right.$, $2 \mathrm{H}), 4.75\left(\mathrm{t}, \mathrm{J}_{1}=4.5 \mathrm{~Hz}, 2 \mathrm{H}\right), 7.15-7.35(\mathrm{~m}, 2 \mathrm{H}), 7.65-7.75$ $(\mathrm{m}, 2 \mathrm{H}), 17.35\left(\mathrm{~d}, \mathrm{~J}_{2}=5.0 \mathrm{~Hz}, 1 \mathrm{H}\right) ;{ }^{31} \mathrm{P} \mathrm{NMR}\left(\mathrm{CD}_{2} \mathrm{Cl}_{2}, \mathrm{Me} \mathrm{eSi}\right)$ $\delta 60.86 ;{ }^{13} \mathrm{C} \mathrm{NMR}\left(\mathrm{CD}_{2} \mathrm{Cl}_{2}, \mathrm{Me}_{4} \mathrm{Si}\right) \delta 26.72,28.09,28.19,30.28$, $35.74,35.99,59.08,69.75,69.80,71.83,72.46,113.48,122.65$, $123.88,130.44,144.12,155.03,278.48$

$\mathbf{R u C l}_{\mathbf{2}}$ (=CH-o-OMDE G)H $\mathbf{H}_{\mathbf{2}}$ Mes (5b). CuCl (0.009 g, 0.094 $\mathrm{mmol}$ ) was added at room temperature to a solution of $\mathrm{RuCl}_{2^{-}}$ $(=\mathrm{CHPh})\left(\mathrm{PC}_{3}\right)\left(\mathrm{H}_{2} \mathrm{l} \mathrm{Mes}\right) \mathbf{1 b}(0.080 \mathrm{~g}, 0.094 \mathrm{mmol})$ in $2 \mathrm{~mL}$ of $\mathrm{CH}_{2} \mathrm{Cl}_{2}$. The reaction was stirred for $15 \mathrm{~min}$, then $\mathbf{1 1}(0.021 \mathrm{~g}$, $0.094 \mathrm{mmol}$ ) was added. The mixture was stirred at $20{ }^{\circ} \mathrm{C}$ for $3 \mathrm{~h}$. The solvent was evaporated under vacuo, and the residue was purified by chromatography [eluent: hexane/EtOAc, 9:1] to yield $0.053 \mathrm{~g}(83 \%)$ of the title compound as a green solid: IR cm ${ }^{-1} 3040$ (s), 2917 (s), 1589 (m), 1263 (s), 1108 (m); ${ }^{1} \mathrm{H}$ NMR $\left(\mathrm{CD}_{2} \mathrm{Cl}_{2}, \mathrm{Me}_{4} \mathrm{Si}\right) \delta 2.45(\mathrm{~s}, 6 \mathrm{H}), 2.50(\mathrm{~s}, 12 \mathrm{H}), 3.35(\mathrm{~s}, 3$ $\mathrm{H}), 3.35-3.50(\mathrm{~m}, 4 \mathrm{H}), 3.60\left(\mathrm{t}, \mathrm{J}_{1}=6.0 \mathrm{~Hz}, 2 \mathrm{H}\right), 4.15(\mathrm{~s}, 4$ $\mathrm{H}), 4.30\left(\mathrm{t}, \mathrm{J}_{1}=6.0 \mathrm{~Hz}, 2 \mathrm{H}\right), 6.95-7.05(\mathrm{~m}, 3 \mathrm{H}), 7.10(\mathrm{~s}, 4$ $\mathrm{H})$, 7.55-7.65 (m, $1 \mathrm{H}), 16.50(\mathrm{~s}, 1 \mathrm{H})$; ${ }^{13} \mathrm{C} \mathrm{NMR}\left(\mathrm{CD}_{2} \mathrm{Cl}_{2}, \mathrm{Me}_{4}\right.$ Si) $\delta 19.45,21.28,52.06,58.99,68.22,69.06,70.79,72.11$, $113.27,122.25,123.84,129.34,129.82,130.02,138.98,139.25$, 144.83, 153.48, 210.55, 292.98; HRMS calculated for $\mathrm{C}_{33} \mathrm{H}_{42} \mathrm{O}_{3} \mathrm{~N}_{2^{-}}$ $\mathrm{Cl}_{2} \mathrm{Ru}$ 686.1619, found 686.1631.

Poly(ethylene glycol)-3400 Di (methanesulfonate) (6). Trifluoromethanesulfonyl chloride $(4.0 \mathrm{~g}, 35.0 \mathrm{mmol})$ was added dropwise at $-20^{\circ} \mathrm{C}$ to a solution of PEG-OH (10.0 g, $2.94 \mathrm{mmol}$ ) and trioctylamine $(12.4 \mathrm{~g}, 35.0 \mathrm{mmol})$ in $40 \mathrm{~mL}$ of $\mathrm{CH}_{2} \mathrm{Cl}_{2}$. The reaction mixture was stirred at room temperature overnight. The product was precipitated in ether, then filtered and dried in vacuo to yield $10.3 \mathrm{~g}(98 \%)$ of the title compound: IR 2871 (s), $1968(\mathrm{~m}), 1466(\mathrm{~s}), 1114(\mathrm{~s}) \mathrm{cm}^{-1}$; ${ }^{1 \mathrm{H} \mathrm{NMR}}\left(\mathrm{CDCl}_{3}\right.$ Mes $\mathrm{Si}) \delta 3.10(\mathrm{~s}, 6 \mathrm{H}), 3.55-3.70(\mathrm{sl}, \sim 310 \mathrm{H}), 3.70-3.75(\mathrm{~m}$, $4 \mathrm{H}), 4.35-4.40(\mathrm{~m}, 4 \mathrm{H}) ;{ }^{13} \mathrm{C} \mathrm{NMR}\left(\mathrm{CDCl}_{3}, \mathrm{Me}_{4} \mathrm{Si}\right) \delta 38.09$, 69.37, 69.72, 70.92; MS (electrospray) $\mathrm{m} / \mathrm{z} \mathrm{n}=72$ : 1673.5 (2 ,$\left.+ 2 \mathrm{H}^{+}\right), \mathrm{n}=78: 1211.6\left(3+, 2 \mathrm{H}^{+} / \mathrm{Na}^{+}\right)$.

Poly(ethylene glycol)-3400 Di(p-vinylbenzene) (7). A solution of 4-vinylphenol $(0.1 \mathrm{~g}, 0.83 \mathrm{mmol})$ in $4 \mathrm{~mL}$ of THF was added to a solution of PEG-OMs $(1.18 \mathrm{~g}, 0.33 \mathrm{mmol})$ and $\mathrm{Cs}_{2} \mathrm{CO}_{3}(0.54 \mathrm{~g}, 1.66 \mathrm{mmol})$ in $8 \mathrm{~mL}$ of THF. The mixture was refluxed for overnight. The solvent was evaporated in vacuo, and the residue was dissolved in $\mathrm{CH}_{2} \mathrm{Cl}_{2}$, then filtered on Celite, precipitated twice in ether, filtered, and dried under vacuo to yield $1.02 \mathrm{~g}(85 \%)$ of the title compound: IR cm $\mathrm{cm}^{-1} 3054$

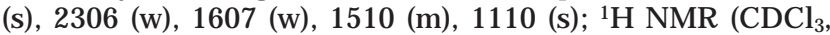
$\left.\mathrm{Me}_{4} \mathrm{Si}\right) \delta 3.55-3.75(\mathrm{sl}, \sim 310 \mathrm{H}), 3.85\left(\mathrm{t}, \mathrm{J}_{1}=4.5 \mathrm{~Hz}, 4 \mathrm{H}\right)$, $4.15\left(\mathrm{t}, \mathrm{J}_{1}=4.5 \mathrm{~Hz}, 4 \mathrm{H}\right), 5.15\left(\mathrm{dd}, \mathrm{J}_{2}=1.0 \mathrm{~Hz}\right.$, J $3=11.0 \mathrm{~Hz}$, $2 \mathrm{H}), 5.60\left(\mathrm{dd}, \mathrm{J}_{2}=1.0 \mathrm{~Hz}, \mathrm{~J}_{4}=17.5 \mathrm{~Hz}, 2 \mathrm{H}\right), 6.65\left(\mathrm{dd}, \mathrm{J}_{3}=\right.$ $\left.11.0 \mathrm{~Hz}, \mathrm{~J}_{4}=17.5 \mathrm{~Hz}, 2 \mathrm{H}\right), 6.90\left(\mathrm{~d}, \mathrm{~J}_{5}=7.0 \mathrm{~Hz}, 4 \mathrm{H}\right), 7.35(\mathrm{~d}$, $\left.\mathrm{J}_{5}=7.0 \mathrm{~Hz}, 4 \mathrm{H}\right) ;{ }^{13} \mathrm{C} \mathrm{NMR}\left(\mathrm{CDCl}_{3}, \mathrm{Me}_{4} \mathrm{Si}\right) \delta 67.82,70.09$, 70.93, 71.20, 112.00, 114.88, 127.90, 130.92, 137.57, 158.94; MS (electrospray) $\mathrm{m} / \mathrm{z} \mathrm{n}=80,1873.6\left(2+, 2 \mathrm{H}^{+}\right) ; \mathrm{n}=92$, $1425.4\left(3+, 3 \mathrm{H}^{+}\right)$.

Poly(ethylene glycol)-3400 Di(benzaldehyde) (8). A solution of salicylaldehyde $(0.43 \mathrm{~g}, 3.52 \mathrm{mmol})$ in $10 \mathrm{~mL}$ of THF was added to a solution of PEGOMs $(5.0 \mathrm{~g}, 1.40 \mathrm{mmol})$ and $\mathrm{Cs}_{2} \mathrm{CO}_{3}(2.3 \mathrm{~g}, 7.03 \mathrm{mmol})$ in $40 \mathrm{~mL}$ of $\mathrm{THF}$. The reaction was refluxed overnight. The solvent was evaporated under vacuo, and the residue was dissolved in $\mathrm{CH}_{2} \mathrm{Cl}_{2}$, then filtered on Celite. The solution was precipitated in ether and in i-PrOH, filtered, and dried under vacuo to yield $4.0 \mathrm{~g}(80 \%)$ of the title compound: IR cm ${ }^{-1} 3055$ (s), 2306 (w), 1687 (s), 1599 (s), 1114 (s); ${ }^{1} \mathrm{H} N M R\left(\mathrm{CDCl}_{3}, \mathrm{Me}_{4} \mathrm{Si}\right) \delta 3.55-3.75(\mathrm{sl}, \sim 310 \mathrm{H}), 3.90(\mathrm{t}$, $\left.\mathrm{J}_{1}=4.5 \mathrm{~Hz}, 4 \mathrm{H}\right), 4.25\left(\mathrm{t}, \mathrm{J}_{1}=4.5 \mathrm{~Hz}, 4 \mathrm{H}\right), 6.95-7.05(\mathrm{~m}, 4$ $\mathrm{H}), 7.45-7.60(\mathrm{~m}, 2 \mathrm{H}), 7.80\left(\mathrm{dd}, \mathrm{J}_{2}=2.0 \mathrm{~Hz}, \mathrm{~J}_{3}=7.5 \mathrm{~Hz}, 2\right.$ $\mathrm{H}), 10.50(\mathrm{~s}, 2 \mathrm{H}) ;{ }^{13} \mathrm{C} N M R\left(\mathrm{CDCl}_{3}, \mathrm{Me}_{4} \mathrm{Si}\right) \delta 68.63,69.89$, 70.93, 71.34, 113.25, 121.33, 125.46, 128.59, 136.27, 161.62, 190.14; MS (electrospray) $\mathrm{m} / \mathrm{z} \mathrm{n}=79,1853.4\left(2+, 2 \mathrm{H}^{+}\right) ; n=$ 87, $1353.5\left(3+, 3 \mathrm{H}^{+}\right)$.

Poly(ethylene glycol)-3400 Di(vinylbenzene) (9). Sodium hydride $(0.106 \mathrm{~g}, 4.43 \mathrm{mmol})$ was added at $0{ }^{\circ} \mathrm{C}$ to a solution of triphenylmethylphosphonium bromide $(0.793 \mathrm{~g}$, $2.22 \mathrm{mmol}$ ) in $10 \mathrm{~mL}$ of THF. The reaction was stirred at $0{ }^{\circ} \mathrm{C}$ for $1 \mathrm{~h}$, then a solution of $8(2.0 \mathrm{~g}, 0.554 \mathrm{mmol})$ in $10 \mathrm{~mL}$ of THF was added dropwise at $0{ }^{\circ} \mathrm{C}$. The mixture was stirred overnight from $0{ }^{\circ} \mathrm{C}$ to room temperature. THF was evaporated, then the residue was dissolved in $\mathrm{CH}_{2} \mathrm{Cl}_{2}$, filtered, and precipitated three times in ether. The product was filtered and dried to yield $1.36 \mathrm{~g}(70 \%)$ of the title compound: I $\mathrm{R} \mathrm{cm}^{-1} 3539$ (m), 2310 (w), 1692 (m), 1453 (s), 1104 (s); ${ }^{1} \mathrm{H} \mathrm{NMR} \mathrm{(CDCl} 3$, $\left.\mathrm{Me}_{4} \mathrm{Si}\right) \delta 3.55-3.80(\mathrm{sl}, \sim 310 \mathrm{H}), 3.85-3.95(\mathrm{~m}, 4 \mathrm{H}), 4.15(\mathrm{t}$, $\left.\mathrm{J}_{1}=4.5 \mathrm{~Hz}, 4 \mathrm{H}\right), 5.25\left(\mathrm{dd}, \mathrm{J}_{2}=1.5 \mathrm{~Hz} \mathrm{~J}_{3}=11.0 \mathrm{~Hz}, 2 \mathrm{H}\right)$, $5.75\left(\mathrm{dd}, \mathrm{J}_{2}=1.5 \mathrm{~Hz}, \mathrm{~J}_{4}=17.5 \mathrm{~Hz}, 2 \mathrm{H}\right), 6.85-7.25(\mathrm{~m}, 8 \mathrm{H})$, $7.50\left(\mathrm{dd}, \mathrm{J}_{5}=1.5 \mathrm{~Hz}, \mathrm{~J}_{6}=7.5 \mathrm{~Hz}, 2 \mathrm{H}\right) ;{ }^{13} \mathrm{C} \mathrm{NMR}\left(\mathrm{CDCl}_{3}\right.$, $\left.\mathrm{Me}_{4} \mathrm{Si}\right) \delta$ 68.37, 70.13, 71.01, 71.27, 112.69, 114.71, 121.30, $126.85,127.36,129.17,132.06,156.34$; MS (electrospray) m/z $\mathrm{n}=75,1765.5\left(2+, 2 \mathrm{H}^{+}\right) ; \mathrm{n}=79,1241.8\left(3+, 2 \mathrm{H}^{+} / \mathrm{Na}^{+}\right)$.

2-[2-(2-Methoxyethoxy)ethoxy]benzaldehyde (10). Methoxyethoxyethane bromide $(1.22 \mathrm{~g}, 6.644 \mathrm{mmol})$ was added to a heterogeneous mixture of salicylal dehyde $(0.9 \mathrm{~g}, 7.38 \mathrm{mmol})$ and $\mathrm{Cs}_{2} \mathrm{CO}_{3}(3.6 \mathrm{~g}, 11.04 \mathrm{mmol})$ in $40 \mathrm{~mL}$ of THF. The reaction was refluxed for $24 \mathrm{~h}$, then the solvent was evaporated. The residue was dissolved in $10 \mathrm{~mL}$ of EtOAc, and the solid was filtered. The filtrate was purified by chromatography [eluant: hexane/EtOAc, 7:3] to yield $1.34 \mathrm{~g}(90 \%)$ of the title compound as a col orless oil: IR cm $\mathrm{cm}^{-1} 2877$ (s), 1732 (s), 1686 (s), 1599 (s), 1484 (s); ${ }^{1} \mathrm{H} \mathrm{NMR}\left(\mathrm{CDCl}_{3}, \mathrm{Me}_{4} \mathrm{Si}\right) \delta 3.40(\mathrm{~s}, 3 \mathrm{H}), 3.55-3.60$ $(\mathrm{m}, 2 \mathrm{H}), 3.70-3.80(\mathrm{~m}, 2 \mathrm{H}), 3.95\left(\mathrm{t}, \mathrm{J}_{1}=4.5 \mathrm{~Hz}, 2 \mathrm{H}\right), 4.25$ $\left(\mathrm{t}, \mathrm{J}_{2}=4.5 \mathrm{~Hz}, 2 \mathrm{H}\right), 6.95-7.10(\mathrm{~m}, 2 \mathrm{H}), 7.50-7.60(\mathrm{~m}, 1 \mathrm{H})$, 7.80-7.90 (m, $1 \mathrm{H}), 10.55(\mathrm{~s}, 1 \mathrm{H}) ;{ }^{13} \mathrm{C} \mathrm{NMR}\left(\mathrm{CDCl}_{3}, \mathrm{Me}_{4} \mathrm{Si}\right) \delta$ 59.51, 68.62, 69.96, 71.33, 72.36, 113.21, 121.37, 125.48, 128.67, 136.31, 161.64, 190.27; MS (electrospray) m/z 225 (M $+\mathrm{H})^{+}$

1-[2-(2-Methoxyethoxy)ethoxy]-2-vinylbenzene (11). Sodium hydride $(0.064 \mathrm{~g}, 2.67 \mathrm{mmol})$ was added to a solution of $\mathrm{Ph}_{3} \mathrm{CH}_{3} \mathrm{P}^{+}, \mathrm{Br}^{-}(0.48 \mathrm{~g}, 1.34 \mathrm{mmol})$ in $\mathrm{THF}$ at $0{ }^{\circ} \mathrm{C}$ for $1 \mathrm{~h} . \mathrm{A}$ solution of $10(0.20 \mathrm{~g}, 0.89 \mathrm{mmol})$ in $10 \mathrm{~mL}$ of THF was added dropwise at $0{ }^{\circ} \mathrm{C}$. The reaction was stirred at $0{ }^{\circ} \mathrm{C}$ for $3 \mathrm{~h}$, then at room temperature overnight. THF was evaporated and the residue was purified by chromatography [eluent: hexane/ EtOAc, 7:3] to yield $0.16 \mathrm{~g}$ (88\%) of the title compound: I $\mathrm{R} \mathrm{cm}^{-1}$ 
2922 (s), 2877 (s), 1601 (m), 1488 (s), 1109 (s); ${ }^{1} \mathrm{H}$ NMR (CDCl $\left.\mathrm{Me}_{4} \mathrm{Si}\right) \delta 3.45(\mathrm{~s}, 3 \mathrm{H}), 3.55-3.65(\mathrm{~m}, 2 \mathrm{H}), 3.70-3.80(\mathrm{~m}, 2$ $\mathrm{H}), 3.90\left(\mathrm{t}, \mathrm{J}_{1}=4.5 \mathrm{~Hz}, 2 \mathrm{H}\right), 4.20\left(\mathrm{t}, \mathrm{J}_{1}=4.5 \mathrm{~Hz}, 2 \mathrm{H}\right), 5.25$ $\left(d d, J_{2}=1.5 \mathrm{~Hz}, \mathrm{~J}_{3}=11.0 \mathrm{~Hz}, 1 \mathrm{H}\right), 5.80\left(\mathrm{dd}, \mathrm{J}_{2}=1.5 \mathrm{~Hz}, \mathrm{~J}_{4}\right.$ $=18.0 \mathrm{~Hz}, 1 \mathrm{H}), 6.85-7.30(\mathrm{~m}, 3 \mathrm{H}), 7.30\left(\mathrm{dd}, \mathrm{J}_{5}=1.5 \mathrm{~Hz}, \mathrm{~J}_{6}\right.$ $=7.5 \mathrm{~Hz}, 1 \mathrm{H}) ;{ }^{13} \mathrm{C} \mathrm{NMR}\left(\mathrm{CDCl}_{3}, \mathrm{Me}_{4} \mathrm{Si}\right) \delta 59.51,68.40,69.98$, 71.23, 72.28, 112.72, 114.75, 121.36, 126.91, 127.45, 129.20, 132.11, 156.36; MS (electrospray) m/z $223(\mathrm{M}+\mathrm{H})^{+}$.

N,N-Diallyl 4-Methylbenzenesulfonamide (13). 68 Triethylamine ( $1.09 \mathrm{~g}, 10.68 \mathrm{mmol}$ ) and tosyl chloride ( $2.0 \mathrm{~g}, 10.48$ $\mathrm{mmol})$ were added to a solution of diallylamine $(1.0 \mathrm{~g}, 10.29$ $\mathrm{mmol}$ ) in $35 \mathrm{~mL}$ of $\mathrm{CH}_{2} \mathrm{Cl}_{2}$. The mixture was stirred at $20{ }^{\circ} \mathrm{C}$ for 1 night. The organic phase was washed twice by an $10 \%$ aqueous solution of $\mathrm{KHSO}_{4}(30 \mathrm{~mL})$ and twice by a saturated aqueous solution of $\mathrm{NaHCO}_{3}(30 \mathrm{~mL})$, then by water $(30 \mathrm{~mL})$. The organic phase was dried on $\mathrm{MgSO}_{4}$ and the solvent was evaporated to yield $2.45 \mathrm{~g}(95 \%)$ of the title compound: ${ }^{1} \mathrm{H}$ NMR $\left(\mathrm{CDCl}_{3}, \mathrm{Me}_{4} \mathrm{Si}\right) \delta 2.45(\mathrm{~s}, 3 \mathrm{H}), 3.85\left(\mathrm{~d}, \mathrm{~J}_{1}=6.0 \mathrm{~Hz}, 4 \mathrm{H}\right), 5.10-$ $5.20(\mathrm{~m}, 4 \mathrm{H}), 5.50-5.75(\mathrm{~m}, 2 \mathrm{H}), 7.30\left(\mathrm{~d}, \mathrm{~J}_{2}=8.5 \mathrm{~Hz}, 2 \mathrm{H}\right)$, $7.70\left(\mathrm{~d}, \mathrm{~J}_{2}=8.5 \mathrm{~Hz}, 2 \mathrm{H}\right)$; MS (electrospray) m/z $252(\mathrm{M}+$ $\mathrm{H})^{+}$.

1-(Toluene-4-sulfonyl)-2,5-dihydro-1H-pyrrole (14).68 With Supported Catalyst 3. Supported catalyst 3 (0.018 g, $0.0035 \mathrm{mmol}$ ) was added to a solution of $\mathrm{N}$-tosyldiallylamine $(0.018 \mathrm{~g}, 0.070 \mathrm{mmol})$ in $5 \mathrm{~mL}$ of $\mathrm{CH}_{2} \mathrm{Cl}_{2}$. The mixture was stirred at $20^{\circ} \mathrm{C}$ for $15 \mathrm{~min}$. The PEG was precipitated in ether, filtered, and analyzed by ${ }^{1} \mathrm{H}$ NMR. The filtrate was evporated to yield $0.012 \mathrm{~g}(77 \%)$ of the title compound after purification on silica gel [eluent: hexane/EtOAc, 7:3].

(b) With Catalyst 5b. Catalyst $\mathbf{5 b}(3.0 \mathrm{mg}, 4.0 \mu \mathrm{mol})$ was added to a solution of $\mathrm{N}$-tosyldiallylamine $(0.020 \mathrm{~g}, 0.080$ $\mathrm{mmol}$ ) in $6 \mathrm{~mL}$ of $\mathrm{CH}_{2} \mathrm{Cl}_{2}$. The mixture was stirred at $20{ }^{\circ} \mathrm{C}$ for $1 \mathrm{~h}$. The residue was checked by NMR and purified by chromatography.

(c) Recycling Conditions 1. Catalyst $\mathbf{4 a}$ or $\mathbf{4 b}(5 \mathrm{~mol} \%$, $10 \% \mathrm{~mol} \mathrm{Ru}$ ) was added to a solution of $\mathrm{N}$-tosyldiallylamine $(0.01 \mathrm{~g}, 0.04 \mathrm{mmol})$ in $2 \mathrm{~mL}$ of $\mathrm{CH}_{2} \mathrm{Cl}_{2}$. The mixture was stirred at $20^{\circ} \mathrm{C}$ for $2 \mathrm{~h}$. The PEG was precpitated in ether, filtered, and analyzed by NMR. The filtrate was evaporated and analyzed by HPLC and by NMR.

(d) Recycling Conditions 2. Catalyst $\mathbf{4 a}$ or $\mathbf{4 b}$ (5 mol \%, $10 \% \mathrm{~mol} \mathrm{Ru}$ ) was added to a solution of $\mathrm{N}$-tosyldiallylamine $(0.010 \mathrm{~g}, 0.040 \mathrm{mmol})$ in $2 \mathrm{~mL}$ of $\mathrm{CH}_{2} \mathrm{Cl}_{2}$. The mixture was stirred at $40{ }^{\circ} \mathrm{C}$ for $1 \mathrm{~h}$. The PEG was precipitated in ether, filtered, and anayzed by NMR. The filtrate was evaporated and analyzed by HPLC and by NMR: ${ }^{1} \mathrm{H} \mathrm{NMR}\left(\mathrm{CDCl}_{3}, \mathrm{Me}_{4} \mathrm{Si}\right)$ $\delta 2.45(\mathrm{~s}, 3 \mathrm{H}), 4.10(\mathrm{~s}, 4 \mathrm{H}), 5.65(\mathrm{~s}, 2 \mathrm{H}), 7.30\left(\mathrm{~d}, \mathrm{~J}_{1}=8.5 \mathrm{~Hz}\right.$, $2 \mathrm{H}$ ), $7.75\left(\mathrm{~d}, \mathrm{~J}_{1}=8.5 \mathrm{~Hz}, 2 \mathrm{H}\right.$ ); MS (electrospray) m/z 224 (M $+\mathrm{H})^{+}$.

Ethyl 2-[Allyl(toluene-4-sulfonyl)amino]pent-4-enoate (15). Allyl bromide $(0.300 \mathrm{~g}, 2.48 \mathrm{mmol})$ was added to a heterogeneous mixture of methyl bromomethylacrylate $(0.460$ $\mathrm{g}, 1.55 \mathrm{mmol}$ ) and $\mathrm{K}_{2} \mathrm{CO}_{3}(1.15 \mathrm{~g}, 8.37 \mathrm{mmol}$ ) in $10 \mathrm{~mL}$ of DMF. The reaction was stirred at room temperature overnight, then $10 \mathrm{~mL}$ of EtOAc and $10 \mathrm{~mL}$ of $\mathrm{H}_{2} \mathrm{O}$ were added. The aqueous phase was washed twice with EtOAc. Organic phases were washed three times with $\mathrm{H}_{2} \mathrm{O}$, dried over $\mathrm{MgSO}_{4}$, and concentrated to yield $0.480 \mathrm{~g}(92 \%)$ of the title compound: IR cm $\mathrm{cm}^{-1}$ $3080(\mathrm{~m}), 2982$ (s), 1732 (s), $1643(\mathrm{~m}), 1598(\mathrm{~m}) ;{ }^{1} \mathrm{H}$ NMR $\left(\mathrm{CDCl}_{3}, \mathrm{Me}_{4} \mathrm{Si}\right) \delta 1.15\left(\mathrm{t}, \mathrm{J}_{1}=7.0 \mathrm{~Hz}, 3 \mathrm{H}\right), 2.45$ (s, 3H ), 2.45$2.80(\mathrm{~m}, 2 \mathrm{H}), 3.85-3.95(\mathrm{~m}, 2 \mathrm{H}), 4.00\left(\mathrm{q}, \mathrm{J}_{1}=7.0 \mathrm{~Hz}, 2 \mathrm{H}\right)$, $4.65\left(\mathrm{dd}, \mathrm{J}_{2}=6.5 \mathrm{~Hz}, \mathrm{~J}_{3}=9.0 \mathrm{~Hz}, 1 \mathrm{H}\right), 5.10-5.25(\mathrm{~m}, 4 \mathrm{H})$, 5.65-5.95 (m, 2 H), $7.30\left(\mathrm{~d}, \mathrm{~J}_{4}=8.5 \mathrm{~Hz}, 2 \mathrm{H}\right), 7.75\left(\mathrm{~d}, \mathrm{~J}_{4}=\right.$ $8.5 \mathrm{~Hz}, 2 \mathrm{H}) ;{ }^{13} \mathrm{C} \mathrm{NMR}\left(\mathrm{CDCl}_{3}, \mathrm{Me}_{4} \mathrm{Si}\right) \delta 14.34,21.94,35.03$, 48.63, 59.89, 61.59, 117.99, 118.83, 128.01, 129.79, 133.77, 135.55, 137.70, 143.74, 170.90; MS (electrospray) m/z 337 (M $+\mathrm{H})^{+}$.

(68) Fürstner, A.; Picquet, M.; Bruneau, C.; Dixneuf, P. H. Chem. Commun. 1998, 12, 1315-1316.
Ethyl 1-(Toluene-4-sulfonyl)-1,2,3,6-tetrahydropyridine2-carboxylate (16). Conditions 3. Catalyst $\mathbf{4 a}$ or $\mathbf{4 b}(5 \mathrm{~mol}$ $\%, 10 \% \mathrm{~mol} \mathrm{Ru}$ ) was added to a solution of $\mathbf{1 5}(0.034 \mathrm{~g}, 0.100$ $\mathrm{mmol}$ ) in $2 \mathrm{~mL}$ of $\mathrm{CH}_{2} \mathrm{Cl}_{2}$. The reaction was stirred at $20{ }^{\circ} \mathrm{C}$ for $2 \mathrm{~h}$. The PEG was precipitated in ether, filtered, and analyzed by NMR. The filtrate was analyzed by HPLC and NMR: IR cm ${ }^{-1} 2984$ (w), 2254 (m), 1736 (m), 1598 (w), 1164 (s); ${ }^{1} \mathrm{H} \mathrm{NMR}\left(\mathrm{CDCl}_{3}, \mathrm{Me}_{4} \mathrm{Si}\right) \delta 1.10\left(\mathrm{t}, \mathrm{J}_{1}=7.0 \mathrm{~Hz}, 3 \mathrm{H}\right), 2.45$ $(\mathrm{s}, 3 \mathrm{H}), 2.60(\mathrm{sl}, 2 \mathrm{H}), 3.80-4.20(\mathrm{~m}, 4 \mathrm{H}), 4.85\left(\mathrm{t}, \mathrm{J}_{2}=4.0\right.$ $\mathrm{Hz}, 1 \mathrm{H}), 5.70(\mathrm{sl}, 2 \mathrm{H}), 7.30\left(\mathrm{~d}, \mathrm{~J}_{3}=8.0 \mathrm{~Hz}, 2 \mathrm{H}\right), 7.70\left(\mathrm{~d}, \mathrm{~J}_{3}\right.$ $=8.0 \mathrm{~Hz}, 2 \mathrm{H}) ;{ }^{13} \mathrm{C} \mathrm{NMR}\left(\mathrm{CDCl}_{3}, \mathrm{Me}_{4} \mathrm{Si}\right) \delta 14.33,21.95,28.30$, 42.59, 53.06, 61.04, 122.70, 123.82, 127.70, 129.87, 136.79, 143.72, 170.85; MS (electrospray) m/z $310(\mathrm{M}+\mathrm{H})^{+}$.

2-Trimethylsilanylethanesulfonyle Chloride. ${ }^{69}$ Phosphorus pentachloride $(3.0 \mathrm{~g}, 14.39 \mathrm{mmol})$ was added slowly at $0{ }^{\circ} \mathrm{C}$ to a solution of sodium 2-trimethylsilyl ethanesulfonate $(1.0 \mathrm{~g}, 4.90 \mathrm{mmol})$ in $6.5 \mathrm{~mL}$ of $\mathrm{CCl}_{4}$. The reaction was stirred at room temperature for $1 \mathrm{~h} 30 \mathrm{~min}$, then transferred in $6 \mathrm{~mL}$ of cold $\mathrm{H}_{2} \mathrm{O}$. The solution was extracted twice with $10 \mathrm{~mL}$ of $\mathrm{CH}_{2} \mathrm{Cl}_{2}$, and the organic phase was washed twice with $10 \mathrm{~mL}$ of a saturated solution of $\mathrm{NaHCO}_{3}$. The organic phase was dried over $\mathrm{MgSO}_{4}$ and filtered, and the solvent was evaporated to yield $0.590 \mathrm{~g}(60 \%)$ of the title compound: ${ }^{1} \mathrm{H} \mathrm{NMR}\left(\mathrm{CDCl}_{3}\right.$, $\left.\mathrm{Me}_{4} \mathrm{Si}\right) \delta 0.10(\mathrm{~s}, 9 \mathrm{H}), 1.30-1.40(\mathrm{~m}, 2 \mathrm{H}), 3.60-3.70(\mathrm{~m}, 2$ $\mathrm{H})$.

Methyl 2-(2-(Trimethylsilanyl)ethanesulfonylamino)pent-4-enoate (17). A solution of 2-(trimethylsilanyl)ethanesulfonyl chloride $(0.600 \mathrm{~g}, 3.67 \mathrm{mmol})$ in $5 \mathrm{~mL}$ of DMF was added dropwise at $0{ }^{\circ} \mathrm{C}$ to a solution of 1-methoxycarbonylbut3-enylammonium chloride $(0.380 \mathrm{~g}, 2.30 \mathrm{mmol})$ and triethylamine (1.862 g, $18.4 \mathrm{mmol}$ ) in $15 \mathrm{~mL}$ of DMF. The reaction was stirred at $0{ }^{\circ} \mathrm{C}$ for $8 \mathrm{~h}$. Then the solvent was evaporated and the residue was purified by chromatography [eluent: hexane/EtOAc, 7:3] to yield $0.360 \mathrm{~g}(59 \%)$ of the title compound: IR cm ${ }^{-1} 3055$ (m), 2306 (w), 1744 (s), 1422 (m), 1265 (s); ${ }^{1} \mathrm{H} N M R\left(\mathrm{CDCl}_{3}, \mathrm{Me}_{4} \mathrm{Si}\right) \delta 0.05(\mathrm{~s}, 9 \mathrm{H}), 1.00-1.15(\mathrm{~m}, 2$ $\mathrm{H}), 2.55\left(\mathrm{t}, \mathrm{J}_{1}=6.5 \mathrm{~Hz}, 2 \mathrm{H}\right), 2.90-3.00(\mathrm{~m}, 2 \mathrm{H}), 3.70(\mathrm{~s}, 3$ $\mathrm{H}), 4.15-4.30(\mathrm{~m}, 1 \mathrm{H}), 4.80\left(\mathrm{~d}, \mathrm{~J}_{2}=9.0 \mathrm{~Hz}, 1 \mathrm{H}\right), 5.15-5.30$ $(\mathrm{m}, 2 \mathrm{H}), 5.60-5.85(\mathrm{~m}, 1 \mathrm{H}) ;{ }^{13} \mathrm{C} \mathrm{NMR}\left(\mathrm{CDCl}_{3}, \mathrm{Me}_{4} \mathrm{Si}\right) \delta-1.59$, 10.85, 38.27, 50.55, 53.10, 55.70, 120.54, 131.92, 172.57; HRMS calcd for $\mathrm{C}_{11} \mathrm{H}_{24} \mathrm{O}_{4} \mathrm{NS}$ S 294.1195 , found 294.1100.

General Procedure for the Alkylation of Amino Ester 17. The alkylating agent was added to a heterogeneous mixture of $\mathbf{1 7}$ and $\mathrm{K}_{2} \mathrm{CO}_{3}$ in $3 \mathrm{~mL}$ of DMF. The reaction was stirred at room temperature overnight, then $5 \mathrm{~mL}$ of EtOAc and $5 \mathrm{~mL}$ of $\mathrm{H}_{2} \mathrm{O}$ were added. The aqueous phase was washed twice with EtOAc. Organic phases were washed three times with $\mathrm{H}_{2} \mathrm{O}$, dried over $\mathrm{MgSO}_{4}$, and concentrated to yield the alkylated compounds $\mathbf{1 8 a}-\mathbf{f}$.

Methyl 2-[Allyl-(2-(trimethylsilanyl)ethanesulfonyl)amino]pent-4-enoate (18a). Allyl bromide (0.043, 0.350 $\mathrm{mmol}), 17(0.058 \mathrm{~g}, 0.218 \mathrm{mmol})$, and $\mathrm{K}_{2} \mathrm{CO}_{3}(0.163 \mathrm{~g}, 1.182$ $\mathrm{mmol})$ were reacted to yield $0.065 \mathrm{~g}(89 \%)$ of the title compound: IR cm $\mathrm{cm}^{-1} 3054$ (s), 2986 (m), 2305 (w), 1742 (m), 1421 (s); ${ }^{1} \mathrm{H}$ NMR $\left(\mathrm{CDCl}_{3}, \mathrm{Me}_{4} \mathrm{Si}\right) \delta 0.05(\mathrm{~s}, 9 \mathrm{H}), 1.00-1.10(\mathrm{~m}, 2$ $\mathrm{H}), 2.50-2.85(\mathrm{~m}, 2 \mathrm{H}), 2.95-3.05(\mathrm{~m}, 2 \mathrm{H}), 3.75(\mathrm{~s}, 3 \mathrm{H}), 3.90-$ $4.00(\mathrm{~m}, 2 \mathrm{H}), 4.55\left(\mathrm{dd}, \mathrm{J}_{1}=6.0 \mathrm{~Hz}, \mathrm{~J}_{2}=9.0 \mathrm{~Hz}, 1 \mathrm{H}\right), 5.15-$ $5.35(\mathrm{~m}, 4 \mathrm{H}), 5.70-6.00(\mathrm{~m}, 2 \mathrm{H}) ;{ }^{13} \mathrm{C} \mathrm{NMR}\left(\mathrm{CDCl}_{3}, \mathrm{Me}_{4} \mathrm{Si}\right) \delta$ $-1.57,10.55,34.98,48.91,50.47,52.71,60.09,118.81,118.96$, 133.92, 135.24, 171.96; HRMS calcd for $\mathrm{C}_{14} \mathrm{H}_{28} \mathrm{O}_{4} \mathrm{NSiS} 334.1508$, found 334.1509.

Methyl 2-[But-3-enyl-(2-(trimethylsilanyl)ethanesulfonyl)amino]pent-4-enoate (18b). 4-Bromo-1-butene (0.045 g, $0.323 \mathrm{mmol}), 17(0.055 \mathrm{~g}, 0.208 \mathrm{mmol})$, and $\mathrm{K}_{2} \mathrm{CO}_{3}(0.155 \mathrm{~g}$, $1.12 \mathrm{mmol})$ were reacted to yield $0.061 \mathrm{~g}(85 \%)$ of the title compound: I R cm ${ }^{-1} 3055$ (m), 2956 (m), 2306 (w), 1744 (s), 1265 (s); ${ }^{1} \mathrm{H}$ NMR $\left(\mathrm{CDCl}_{3}, \mathrm{Me}_{4} \mathrm{Si}\right) \delta 0.05(\mathrm{~s}, 9 \mathrm{H}), 1.00-1.15(\mathrm{~m}, 2$ H), 2.30-2.65 (m, 3 H), 2.70-3.10 (m, 3 H), 3.15-3.45 (m, 2

(69) Weinreb, S. M.; Demko, D. M.; Lessen, T. A.; Demers, J. P. Tetrahedron Lett. 1986, 27, 2099-2102. 
$\mathrm{H}), 3.75(\mathrm{~s}, 3 \mathrm{H}), 4.50\left(\mathrm{dd}, \mathrm{J}_{1}=6.5 \mathrm{~Hz}, \mathrm{~J}_{2}=9.0 \mathrm{~Hz}, 1 \mathrm{H}\right)$, 5.05-5.25 (m, $4 \mathrm{H}), 5.65-5.95(\mathrm{~m}, 2 \mathrm{H}) ;{ }^{13} \mathrm{C} \mathrm{NMR}\left(\mathrm{CDCl}_{3}, \mathrm{Me}_{4}\right.$ Si) $\delta-1.56,10.57,35.60,36.91,46.09,49.69,52.76,60.41$, $117.55,119.01,133.79,135.10,171.92$; HRMS cal cd for $\mathrm{C}_{15} \mathrm{H}_{30} \mathrm{O}_{4^{-}}$ NSiS 348.1665, found 348.1659.

Methyl 2-[Pent-4-enyl-(2-(trimethylsilanyl)ethanesulfonyl)amino]pent-4-enoate (18c). 5-Bromo-1-pentene $(0.05 \mathrm{~g}$, $0.33 \mathrm{mmol}), 17(0.055 \mathrm{~g}, 0.208 \mathrm{mmol})$, and $\mathrm{K}_{2} \mathrm{CO}_{3}(0.155 \mathrm{~g}$, $1.121 \mathrm{mmol}$ ) were reacted to yield $0.068 \mathrm{~g}(91 \%)$ of the title compound: IR cm ${ }^{-1} 3056(\mathrm{~m}), 2955(\mathrm{~m}), 2306(\mathrm{w}), 1742$ (s), 1266 (s); ${ }^{1} \mathrm{H} \mathrm{NMR}\left(\mathrm{CDCl}_{3}, \mathrm{Me}_{4} \mathrm{Si}\right) \delta 0.05(\mathrm{~s}, 9 \mathrm{H}), 1.00-1.15$ (m, $2 \mathrm{H}), 1.65-1.90(\mathrm{~m}, 2 \mathrm{H}), 2.00-2.15$ (m, $2 \mathrm{H}), 2.45-2.60$ (m, $1 \mathrm{H}), 2.70-2.85(\mathrm{~m}, 1 \mathrm{H}), 2.90-3.05(\mathrm{~m}, 2 \mathrm{H}), 3.10-3.40$ $(\mathrm{m}, 2 \mathrm{H}), 3.75(\mathrm{~s}, 3 \mathrm{H}), 4.50\left(\mathrm{dd}, \mathrm{J}_{1}=6.5 \mathrm{~Hz}, \mathrm{~J}_{2}=9.0 \mathrm{~Hz}, 1 \mathrm{H}\right)$, 4.95-5.30 (m, 4 H), 5.65-5.95 (m, $2 \mathrm{H}) ;{ }^{13} \mathrm{C} \mathrm{NMR}\left(\mathrm{CDCl}_{3}, \mathrm{Me}_{4}-\right.$ Si) $\delta-1.56,10.59,30.14,31.48,35.26,46.23,49.65,52.74$, $60.34,115.81,118.94,133.86,137.75,171.98$; HRMS calcd for $\mathrm{C}_{16} \mathrm{H}_{32} \mathrm{O}_{4} \mathrm{NS}$ iS 362.1821, found 362.1825.

Methyl 2-[(2-Methylallyl)-(2-(trimethylsilanyl)ethanesulfonyl)amino]pent-4-enoate (18d). Methallyl bromide $(0.040 \mathrm{~g}, 0.302 \mathrm{mmol}), 17(0.050 \mathrm{~g}, 0.170 \mathrm{mmol})$, and $\mathrm{K}_{2} \mathrm{CO}_{3}$ $(0.127 \mathrm{~g}, 0.918 \mathrm{mmol})$ were reacted to yield $0.049 \mathrm{~g}(83 \%)$ of the title compound: I R cm$~^{-1} 3054(\mathrm{~s}), 2986(\mathrm{~m}), 2305(\mathrm{~m}), 1742$ (m), 1265 (s); ${ }^{1} \mathrm{H} \mathrm{NMR}\left(\mathrm{CDCl}_{3}, \mathrm{Me}_{4} \mathrm{Si}\right) \delta 0.05$ (s, $\left.9 \mathrm{H}\right), 1.00-$ $1.15(\mathrm{~m}, 2 \mathrm{H}), 1.80(\mathrm{~s}, 3 \mathrm{H}), 2.55-2.90(\mathrm{~m}, 2 \mathrm{H}), 2.95-3.05(\mathrm{~m}$, $2 \mathrm{H}), 3.75(\mathrm{~s}, 3 \mathrm{H}), 3.85\left(\mathrm{q}, \mathrm{J}_{1}=15.5 \mathrm{~Hz}, 2 \mathrm{H}\right), 4.45\left(\mathrm{t}, \mathrm{J}_{2}=7.5\right.$ $\mathrm{Hz}, 1 \mathrm{H}), 5.00\left(\mathrm{~d}, \mathrm{~J}_{3}=11.5 \mathrm{~Hz}, 2 \mathrm{H}\right), 5.10-5.25(\mathrm{~m}, 2 \mathrm{H}), 5.70$ $5.95(\mathrm{~m}, 1 \mathrm{H}) ;{ }^{13} \mathrm{C} \mathrm{NMR}\left(\mathrm{CDCl}_{3}, \mathrm{Me}_{4} \mathrm{Si}\right) \delta-1.56,10.53,20.72$, 35.38, 50.10, 52.61, 52.96, 60.56, 115.04, 118.78, 134.27, 141.92, 171.58; HRMS calcd for $\mathrm{C}_{15} \mathrm{H}_{30} \mathrm{O}_{4} \mathrm{NSiS} 348.1665$, found 348.1650.

Methyl 2-[(2-(Methoxycarbonyl)allyl)-(2-(trimethylsiIanyl)ethanesulfonyl)amino]pent-4-enoate (18e). M ethyl 2-bromomethylacrylate $(0.060 \mathrm{~g}, 0.33 \mathrm{mmol}), 17(0.055 \mathrm{~g}, 0.21$ $\mathrm{mmol})$, and $\mathrm{K}_{2} \mathrm{CO}_{3}(0.155 \mathrm{~g}, 1.12 \mathrm{mmol})$ to yield $0.068 \mathrm{~g}(83 \%)$ of the title compound: IR cm $\mathrm{cm}^{-1} 3055$ (w), $2954(\mathrm{~m}), 2306(\mathrm{w})$, 1741 (s), 1724 (s), 1266 (s); ${ }^{1} \mathrm{H}$ NMR (CDCl, $\left.\mathrm{Me}_{4} \mathrm{Si}\right) \delta 0.05$ (s, $9 \mathrm{H}), 1.00-1.15(\mathrm{~m}, 2 \mathrm{H}), 2.45-2.85(\mathrm{~m}, 2 \mathrm{H}), 2.95-3.10(\mathrm{~m}, 2$ $\mathrm{H}), 3.75(\mathrm{~s}, 3 \mathrm{H}), 3.80(\mathrm{~s}, 3 \mathrm{H}), 4.20\left(\mathrm{~d}, \mathrm{~J}_{1}=6.0 \mathrm{~Hz}, 2 \mathrm{H}\right), 4.50$ $\left(d d, J_{2}=6.5 \mathrm{~Hz}, \mathrm{~J}_{3}=8.5 \mathrm{~Hz}, 1 \mathrm{H}\right), 5.10-5.25(\mathrm{~m}, 2 \mathrm{H}), 5.60-$ $5.75(\mathrm{~m}, 1 \mathrm{H}), 6.05(\mathrm{~s}, 1 \mathrm{H}), 6.50(\mathrm{~s}, 1 \mathrm{H}) ;{ }^{13} \mathrm{C} \mathrm{NMR}\left(\mathrm{CDCl}_{3}\right.$, $\mathrm{Me}_{4} \mathrm{Si}$ ) $\delta-1.56,10.45,34.96,46.97,50.01,52.44,52.72,60.46$, 118.93, 129.10, 133.87, 136.88, 166.80, 171.65; HRMS calcd for $\mathrm{C}_{16} \mathrm{H}_{30} \mathrm{O}_{6} \mathrm{NSiS} 392.1563$, found 392.1565.

Methyl 2-[Prop-2-ynyl-(2-(trimethylsilanyl)ethanesulfonyl)amino]pent-4-enoate (18f). Propargyl bromide $(0.035 \mathrm{~g}, 0.302 \mathrm{mmol}), 17(0.060 \mathrm{~g}, 0.205 \mathrm{mmol})$, and $\mathrm{K}_{2} \mathrm{CO}_{3}$ $(0.153 \mathrm{~g}, 1.106 \mathrm{mmol})$ were reacted to yield $0.058 \mathrm{~g}(86 \%)$ of the title compound: IR cm cm $^{-1} 3054$ (s), 2986 (m), 2306 (w), 1743 (s), 1265 (s); ${ }^{1} \mathrm{H}$ NMR $\left(\mathrm{CDCl}_{3}, \mathrm{Me}_{4} \mathrm{Si}\right) \delta 0.05$ (s, $\left.9 \mathrm{H}\right), 1.05-$ $1.15(\mathrm{~m}, 2 \mathrm{H}), 2.30\left(\mathrm{t}, \mathrm{J}_{1}=2.5 \mathrm{~Hz}, 1 \mathrm{H}\right), 2.55-2.90(\mathrm{~m}, 2 \mathrm{H})$, 3.60-3.70 (m, $2 \mathrm{H}), 3.70(\mathrm{~s}, 3 \mathrm{H}), 4.20\left(\mathrm{q}, \mathrm{J}_{1}=2.5 \mathrm{~Hz}, 2 \mathrm{H}\right)$, $4.55\left(\mathrm{dd}, \mathrm{J}_{2}=6.5 \mathrm{~Hz} \mathrm{~J}_{3}=9.0 \mathrm{~Hz}, 1 \mathrm{H}\right), 5.15-5.30(\mathrm{~m}, 2 \mathrm{H})$, 5.75-5.95 (m, 1 H); ${ }^{13} \mathrm{C} \mathrm{NMR}\left(\mathrm{CDCl}_{3}, \mathrm{Me}_{4} \mathrm{Si}\right) \delta-1.55,10.38$, 34.35, 34.54, 50.85, 52.71, 59.61, 73.18, 79.67, 119.30, 133.49, 171.38; HRMS calcd for $\mathrm{C}_{14} \mathrm{H}_{26} \mathrm{O}_{4} \mathrm{NSIS} 332.1352$, found 332.1358.

General Procedure for Ring-Closing Metathesis of Aminoesters $\mathbf{1 8} \mathbf{a}-\mathbf{f}$. The supported catalyst $\mathbf{4 a}$ or $\mathbf{4 b}$ was added to a solution of $\mathbf{1 8 a}-\mathbf{f}$ in $5 \mathrm{~mL}$ of $\mathrm{CH}_{2} \mathrm{Cl}_{2}$. The reaction was stirred at $20^{\circ} \mathrm{C}$ for $8 \mathrm{~h}$. PEG was precipitated in ether and filtered. The filtrate was evaporated to yield the cyclic compounds $19 \mathbf{a}-\mathbf{f}$ after purification by chromatography [eluent: hexane/EtOAc, 7:3].

Methyl 1-(2-(Trimethylsilanyl)ethanesulfonyl)-1,2,3,6tetrahydropyridine-2-carboxylate (19a). $4 a$ (0.037 g, 0.008 $\mathrm{mmol})$ and 18a $(0.050 \mathrm{~g}, 0.160 \mathrm{mmol})$ were reacted to yield $0.044 \mathrm{~g}(91 \%)$ of the title compound: IR cm $\mathrm{cm}^{-1} 3055(\mathrm{~m}), 2956$ (m), 2306 (w), 1743 (s), 1265 (s); ${ }^{1 H} \mathrm{NMR}\left(\mathrm{CDCl}_{3}, \mathrm{Me}_{4} \mathrm{Si}\right) \delta$ $0.05(\mathrm{~s}, 9 \mathrm{H}), 1.05-1.15(\mathrm{~m}, 2 \mathrm{H}), 2.65(\mathrm{sl}, 2 \mathrm{H}), 2.95-3.10(\mathrm{~m}$, $2 \mathrm{H}), 3.75(\mathrm{~s}, 3 \mathrm{H}), 3.95-4.15(\mathrm{~m}, 2 \mathrm{H}), 4.80\left(\mathrm{dd}, \mathrm{J}_{1}=3.0 \mathrm{~Hz}\right.$,
$\left.\mathrm{J}_{2}=5.5 \mathrm{~Hz}, 1 \mathrm{H}\right), 5.65-5.90(\mathrm{~m}, 2 \mathrm{H}) ;{ }^{13} \mathrm{C} \mathrm{NMR}\left(\mathrm{CDCl}_{3}, \mathrm{Me}_{4-}\right.$ Si) $\delta-1.56,10.52,28.31,42.84,48.73,52.92,53.54,123.15$, 123.98, 171.98; HRMS calcd for $\mathrm{C}_{12} \mathrm{H}_{24} \mathrm{O}_{4} \mathrm{NSiS} 306.1195$, found 306.1193.

Methyl 1-(2-(Trimethylsilanyl)ethanesulfonyl)-2,3,6,7tetrahydro-1H-azepine-2-carboxylate (19b). $4 a$ (0.032 g, $0.007 \mathrm{mmol})$ and $\mathbf{1 8 b}(0.050 \mathrm{~g}, 0.144 \mathrm{mmol})$ were reacted to yield $0.044 \mathrm{~g}(95 \%)$ of the title compound: IR cm-1 $3058(\mathrm{w})$, 3030 (w), 2954 (s), 1744 (s), 1438 (m); ${ }^{1} \mathrm{H} \mathrm{NMR}\left(\mathrm{CDCl}_{3}, \mathrm{Me}_{4-}\right.$ Si) $\delta 0.05(\mathrm{~s}, 9 \mathrm{H}), 1.05-1.15(\mathrm{~m}, 2 \mathrm{H}), 2.30-2.95(\mathrm{~m}, 4 \mathrm{H})$, 2.95-3.05 (m, $2 \mathrm{H}), 3.35-3.50(\mathrm{~m}, 1 \mathrm{H}), 3.70(\mathrm{~s}, 3 \mathrm{H}), 3.70-$ $3.85(\mathrm{~m}, 1 \mathrm{H}), 4.85\left(\mathrm{dd}, \mathrm{J}_{1}=4.0 \mathrm{~Hz}, \mathrm{~J}_{2}=7.0 \mathrm{~Hz}, 1 \mathrm{H}\right), 5.65-$ $5.90(\mathrm{~m}, 2 \mathrm{H}) ;{ }^{13} \mathrm{C} \mathrm{NMR}\left(\mathrm{CDCl}_{3}, \mathrm{Me}_{4} \mathrm{Si}\right) \delta-1.56,10.59,30.82$, 31.54, 44.32, 49.52, 52.73, 59.13, 126.71, 132.42, 172.29; HRMS calcd for $\mathrm{C}_{19} \mathrm{H}_{26} \mathrm{O}_{4} \mathrm{NS}$ S 320.1352, found 332.1353.

Methyl 1-(2-(Trimethylsilanyl)ethanesulfonyl)-1,2,3,6,7,8-hexahydroazocine-2-carboxylate (18c). $4 a(0.031 \mathrm{~g}$, $0.007 \mathrm{mmol})$ and $18 \mathrm{c}(0.050 \mathrm{~g}, 0.139 \mathrm{mmol})$ were reacted to yield $0.043 \mathrm{~g}(93 \%)$ of the title compound: IR $\mathrm{cm}^{-1} 3055(\mathrm{~m})$, 2955 (m), 2306 (w), 1741 (s), 1328 (s); ${ }^{1} \mathrm{H} \mathrm{NMR} \mathrm{(CDCl}{ }_{3}, \mathrm{Me}_{4}{ }^{-}$ Si) $\delta 0.05(\mathrm{~s}, 9 \mathrm{H}), 1.05-1.15(\mathrm{~m}, 2 \mathrm{H}), 1.40-1.60(\mathrm{~m}, 1 \mathrm{H})$, 1.95-2.45 (m, $3 \mathrm{H}), 2.60-2.70(\mathrm{~m}, 2 \mathrm{H}), 2.80-3.10(\mathrm{~m}, 3 \mathrm{H})$, $3.65-3.80(\mathrm{~m}, 1 \mathrm{H}), 3.80(\mathrm{~s}, 3 \mathrm{H}), 4.65\left(\mathrm{dd}, \mathrm{J}_{1}=5.0 \mathrm{~Hz}, \mathrm{~J}_{2}=\right.$ $7.5 \mathrm{~Hz}, 1 \mathrm{H}), 5.70-6.00(\mathrm{~m}, 2 \mathrm{H}) ;{ }^{13} \mathrm{C} \mathrm{NMR}\left(\mathrm{CDCl}_{3}, \mathrm{Me}_{4} \mathrm{Si}\right) \delta$ -1.56, 10.62, 24.76, 29.98, 30.59, 46.62, 48.51, 52.80, 60.83, $126.40,134.17,172.33$; HRMS calcd for $\mathrm{C}_{14} \mathrm{H}_{28} \mathrm{O}_{4} \mathrm{NSiS} 334.1508$, found 334.1508 .

Methyl 5-Methyl-1-(2-(trimethylsilanyl)ethanesulfonyl)-1,2,3,6-tetrahydropyridine-2-carboxylate (19d). 4a $(0.032 \mathrm{~g}, 0.007 \mathrm{mmol})$ and $\mathbf{1 8 d}(0.050 \mathrm{~g}, 0.144 \mathrm{mmol})$ were reacted to yield $0.040 \mathrm{~g}(87 \%)$ of the title compound: IR $\mathrm{cm}^{-1}$ 3057 (w), 2954 (s), 1744 (s), 1439 (m), 1332 (s); ${ }^{1} \mathrm{H} \mathrm{NMR} \mathrm{(CDCl}{ }_{3}$, $\left.\mathrm{Me}_{4} \mathrm{Si}\right) \delta 0.05(\mathrm{~s}, 9 \mathrm{H}), 1.05-1.15(\mathrm{~m}, 2 \mathrm{H}), 1.70(\mathrm{~s}, 3 \mathrm{H}), 2.60$ (sl, $2 \mathrm{H}), 2.95-3.10(\mathrm{~m}, 2 \mathrm{H}), 3.75(\mathrm{~s}, 3 \mathrm{H}), 3.75-4.00(\mathrm{~m}, 2$ $\mathrm{H}), 4.75(\mathrm{dd}, \mathrm{J}=3.5 \mathrm{~Hz}$, J $=5.0 \mathrm{~Hz}, 1 \mathrm{H}), 5.50(\mathrm{~s}, 1 \mathrm{H}) ;{ }^{13} \mathrm{C}$ $\mathrm{NMR}\left(\mathrm{CDCl}_{3}, \mathrm{Me}_{4} \mathrm{Si}\right) \delta-1.55,10.51,20.85,28.21,46.18,48.70$, $52.86,53.34,117.56,131.15,172.17$; $\mathrm{HRMS}$ calcd for $\mathrm{C}_{13} \mathrm{H}_{26} \mathrm{O}_{4^{-}}$ NSiS 320.1352, found 320.1369.

Dimethyl 1-(2-(Trimethylsilanyl)ethanesulfonyl)-1,2,3,6tetrahydropyridine-2,5-dicarboxylate (19e). 4b (0.059 g, $0.013 \mathrm{mmol})$ and $18 \mathrm{e}(0.100 \mathrm{~g}, 0.260 \mathrm{mmol})$ were reacted to yield $0.084 \mathrm{~g}$ (89\%) of the title compound: IR cm-1 $3058(\mathrm{~m})$, 2955 (s), 1743 (s), 1719 (s), 1438 (s); ${ }^{1} \mathrm{H}$ NMR ( $\left.\mathrm{CDCl}_{3}, \mathrm{Me}_{4} \mathrm{Si}\right)$ $\delta 0.05(\mathrm{~s}, 9 \mathrm{H}), 1.05-1.15(\mathrm{~s}, 2 \mathrm{H}), 2.65-3.10(\mathrm{~m}, 4 \mathrm{H}), 3.70(\mathrm{~s}$, $3 \mathrm{H}), 3.75(\mathrm{~s}, 3 \mathrm{H}), 4.00-4.10(\mathrm{~m}, 1 \mathrm{H}), 4.40\left(\mathrm{~d}, \mathrm{~J}_{1}=17.0 \mathrm{~Hz}\right.$, $1 \mathrm{H}), 4.85\left(\mathrm{dd}, \mathrm{J}_{2}=1.5 \mathrm{~Hz}, \mathrm{~J}_{3}=6.5 \mathrm{~Hz}, 1 \mathrm{H}\right), 7.00-7.10(\mathrm{~m}$, $1 \mathrm{H}) ;{ }^{13} \mathrm{C} \mathrm{NMR}\left(\mathrm{CDCl}_{3}, \mathrm{Me}_{4} \mathrm{Si}\right) \delta-1.56,10.47,28.64,41.73$, 49.09, 52.34, 52.65, 53.13, 126.47, 127.60, 135.46, 165.33, 171.19; HRMS calcd for $\mathrm{C}_{14} \mathrm{H}_{26} \mathrm{O}_{6} \mathrm{NSiS} 364.1250$, found 364.1259.

Methyl 1-(2-(Trimethylsilanyl)ethanesulfonyl)-5-vinyl1,2,3,6-tetrahydropyridine-2-carboxylate (19f). $4 a(0.037$ $\mathrm{g}, 0.008 \mathrm{mmol})$ and $18 \mathrm{f}(0.050 \mathrm{~g}, 0.164 \mathrm{mmol})$ were used to yield $0.046 \mathrm{~g}(86 \%)$ of the title compound: IR cm $\mathrm{cm}^{-1} 3057(\mathrm{w})$, 2954 (m), 2306 (w), 1742 (s), 1335 (s); ${ }^{1} \mathrm{H} \mathrm{NMR} \mathrm{(CDCl}{ }_{3}, \mathrm{Me}_{4}{ }^{-}$ Si) $\delta 0.05(\mathrm{~s}, 9 \mathrm{H}), 1.05-1.15(\mathrm{~m}, 2 \mathrm{H}), 2.75(\mathrm{sl}, 2 \mathrm{H}), 3.00-$ $3.10(\mathrm{~m}, 2 \mathrm{H}), 3.75(\mathrm{~s}, 3 \mathrm{H}), 4.05\left(\mathrm{~d}, \mathrm{~J}_{1}=16.0 \mathrm{~Hz}, 1 \mathrm{H}\right), 4.30$ $\left(\mathrm{d}, \mathrm{J}_{1}=16.0 \mathrm{~Hz}, 1 \mathrm{H}\right), 4.80\left(\mathrm{q}, \mathrm{J}_{2}=3.0 \mathrm{~Hz}, 1 \mathrm{H}\right), 5.00-5.15$ $(\mathrm{m}, 2 \mathrm{H}), 5.80(\mathrm{~s}, 1 \mathrm{H}), 6.30\left(\mathrm{dd}, \mathrm{J}_{3}=11.0 \mathrm{~Hz}, \mathrm{~J}_{4}=18.0 \mathrm{~Hz}, 1\right.$ $\mathrm{H}) ;{ }^{13} \mathrm{C} \mathrm{NMR}\left(\mathrm{CDCl}_{3}, \mathrm{Me}_{4} \mathrm{Si}\right) \delta-1.54,10.51,28.56,42.05$, 48.87, 52.98, 53.55, 112.52, 144.31, 133.02, 136.42, 171.80; HRMS calcd for $\mathrm{C}_{14} \mathrm{H}_{26} \mathrm{O}_{4} \mathrm{NS}$ S 332.1352 , found 332.1333 .

tert-Butyl Allylcarbamoate. Triethylamine (2.90 g, 29.4 $\mathrm{mmol}$ ) and tert-butyloxycarbonyl anhydride (5.8 g, $26.7 \mathrm{mmol}$ ) were added at $0{ }^{\circ} \mathrm{C}$ to a solution of allylamine $(1.52 \mathrm{~g}, 26.7$ $\mathrm{mmol}$ ) in $20 \mathrm{~mL}$ of $\mathrm{CH}_{2} \mathrm{Cl}_{2}$. The reaction was stirred at $20^{\circ} \mathrm{C}$ for $8 \mathrm{~h}$. The mixture was washed twice with $20 \mathrm{~mL}$ of an aqueous solution of $1 \mathrm{~N} \mathrm{HCl}$. The organic phase was dried over $\mathrm{MgSO}_{4}$, and the solvent was evaporated to yield $4.0 \mathrm{~g}$ (95\%) of the title compound: IR cm $3448(\mathrm{w}), 2979(\mathrm{~m}), 1707(\mathrm{~s})$,

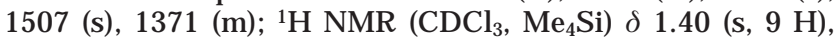


$3.70(\mathrm{~s}, 2 \mathrm{H}), 4.65(\mathrm{sl}, 1 \mathrm{H}), 5.05-5.25(\mathrm{~m}, 2 \mathrm{H}), 5.70-5.95(\mathrm{~m}$, $1 \mathrm{H})$; MS (electrospray) $\mathrm{m} / \mathrm{z} 158(\mathrm{M}+\mathrm{H})^{+}$.

Methyl 2-[(Allyl-tert-butoxycarbonylamino)methyl]acrylate (20). Sodium hydride $(0.069 \mathrm{~g}, 1.720 \mathrm{mmol})$ was added at $0{ }^{\circ} \mathrm{C}$ to a solution of tert-butyl allylcarbamoate $(0.180$ $\mathrm{g}, 1.150 \mathrm{mmol})$ and methyl 2-bromomethylacrylate $(0.308 \mathrm{~g}$, $1.720 \mathrm{mmol}$ ) in $5 \mathrm{~mL}$ of DMF. The reaction was stirred at 0 ${ }^{\circ} \mathrm{C}$ for $30 \mathrm{~min}$, then at room temperature for $2 \mathrm{~h}$, and $10 \mathrm{~mL}$ of EtOAc and $10 \mathrm{~mL}$ of $\mathrm{H}_{2} \mathrm{O}$ were added. The aqueous phase was washed twice with EtOAc. The organic phase was washed three times with $\mathrm{H}_{2} \mathrm{O}$, dried over $\mathrm{MgSO}_{4}$, and concentrated. The residue was purified by chromatography [eluent: hexane/ EtOAc, 8:2] to yield $0.211 \mathrm{~g}(72 \%)$ of the title compound: IR $\mathrm{cm}^{-1} 2977$ (w), 1715 (s), 1691 (s), 1457 (m), 1406 (m); ${ }^{1} \mathrm{H}$ NMR $\left(\mathrm{CDCl}_{3}, \mathrm{Me}_{4} \mathrm{Si}\right) \delta 1.45(\mathrm{~s}, 9 \mathrm{H}), 3.75(\mathrm{~s}, 3 \mathrm{H}), 3.85(\mathrm{sl}, 2 \mathrm{H}), 4.10$ (sl, $2 \mathrm{H}), 5.05-5.20(\mathrm{~m}, 2 \mathrm{H}), 5.60(\mathrm{~s}, 1 \mathrm{H}), 5.70-5.90(\mathrm{~m}, 1$ $\mathrm{H}), 6.30(\mathrm{~s}, 1 \mathrm{H})$; MS (electrospray) $\mathrm{m} / \mathrm{z} 256(\mathrm{M}+\mathrm{H})^{+}$.

1-tert-Butyl-3-methyl-2,5-dihydropyrrole-1,3-dicarboxylate (21). Supported catalyst $\mathbf{4 b}(0.050 \mathrm{~g}, 0.011 \mathrm{mmol})$ was added to a solution of $20(0.054 \mathrm{~g}, 0.222 \mathrm{mmol})$ in $5 \mathrm{~mL}$ of
$\mathrm{CH}_{2} \mathrm{Cl}_{2}$. The reaction was stirred at $20^{\circ} \mathrm{C}$ for $24 \mathrm{~h}$. PEG was preci pitated and filtered. The filtrate was evaporated to yield $0.042 \mathrm{~g}(83 \%)$ of the title compound after purification by chromatography [eluent: hexane/EtOAc, 7:3]: IR cm ${ }^{-1} 2980$

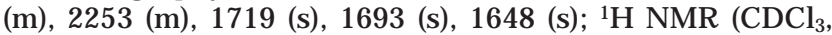
$\left.\mathrm{Me}_{4} \mathrm{Si}\right) \delta 1.50(\mathrm{~s}, 9 \mathrm{H}), 3.80(\mathrm{~s}, 3 \mathrm{H}), 4.35(\mathrm{sl}, 4 \mathrm{H}), 6.70-6.80$ $(\mathrm{m}, 1 \mathrm{H}) ;{ }^{13} \mathrm{C} \mathrm{NMR}\left(\mathrm{CDCl}_{3}, \mathrm{Me}_{4} \mathrm{Si}\right) \delta 2$ conformers 28.87, (52.22, 52.43), (54.06, 54.27), (80.23, 80.32), (132.32, 132.43), (137.28, 137.36), 154.48, 163.61; HRMS calcd for $\mathrm{C}_{11} \mathrm{H}_{18} \mathrm{O}_{4} \mathrm{~N} 228.1236$, found 228.1244 .

Acknowledgment. We thank the CNRS and the MENRT for financial support. 